\title{
On the History of Meridional Overturning Circulation Schematic Diagrams
}

\author{
Philip L. Richardson \\ Woods Hole Oceanographic Institution \\ Physical Oceanography Department, MS \#21 \\ 360 Woods Hole Road \\ Woods Hole, MA 02543 USA \\ E-mail: prichardson@whoi.edu \\ July 23, 2007
}




\begin{abstract}
Recent global warming caused by humans and the prediction of a reduced Atlantic Ocean meridional overturning circulation in the future has increased interest in the role of the overturning circulation in climate change. A schematic diagram of the overturning circulation called the "Great Ocean Conveyor Belt," published by Wallace Broecker in 1987, has become a popular image that emphasizes the inter-connected ocean circulation and the northward flux of heat in the Atlantic. This would appear to be a good time to review the development of the conveyor belt concept and summarize the history of overturning circulation schematics.

In the nineteenth century it was thought that symmetric overturning circulation cells were located on either side of the equator in the Atlantic. As new hydrographic measurements were obtained in the late nineteenth century and early twentieth century, circulation schematics in the early twentieth century began to show the inter-hemispheric overturning circulation in the Atlantic. In the second half of the twentieth century schematics showed the global ocean overturning circulation including connections between the Atlantic and the Pacific and Indian Oceans. Some recent schematics of the overturning circulation show its complexities, but as more information is included these schematics have also become complex and not as easy to understand as the simple Broecker 1987 version.
\end{abstract}

Keywords: ocean conveyor belt, meridional overturning circulation. thermohaline circulation, global ocean circulation, schematic circulation diagrams, history of ocean circulation.

Regional terms: global ocean, Atlantic Ocean, Southern Ocean, Indian Ocean, Pacific Ocean 


\section{Atlantic circulation}

\subsection{Rennell 1832}

In 1832, Jane Rodd, daughter of Major James Rennell, published his chart of surface currents of the Atlantic (Rennell, 1832) (Fig. 1). Rennell had been a surveyor for the Royal Navy and East India Company and had a great interest in ocean circulation. As navigation improved in the eighteenth century, ship captains began to measure surface currents by calculating the difference between velocity of the ship measured using position fixes and the dead-reckoned velocity of the ship through the water. Rennell collected available ship drift velocities and mapped with arrows major ocean currents that we now know as the Gulf Stream, Brazil Current, South Atlantic Current, and Benguela Current. In addition to showing the circulation of the subtropical gyres in the North and South Atlantic, Rennell's chart shows the first evidence of a possible inter-hemispheric overturning circulation in the Atlantic; a clear pathway is indicated by arrows westward around southern Africa, northwestward through the eastern South Atlantic, northward across the equator in the west, and into the Caribbean and Gulf Stream. Later improved ship drift charts continued to show the northward flux across the equator in the North Brazil Current. Generally these charts indicate a northward flow of warm surface water from the Gulf Stream region into the northern North Atlantic and a southward flow of colder water from Greenland, along the coast of Labrador, around the Grand Banks and westward north of the Gulf Stream. A good summary of early charts and schematics based on ship drifts is given by Peterson et al. (1996).

\subsection{Lenz 1845}


The earliest recorded deep temperature measurements in the subtropical Atlantic were made in 1750 by Captain Henry Ellis of the British slave ship Earl of Halifax. They revealed that warm subtropical water was confined to a relatively thin surface layer overlying much colder water (Ellis, 1851; Wüst, 1968; Deacon, 1971; Warren, 1981). Count Rumford (1798) who was born American as Benjamin Thompson and who served with the British, was knighted, eventually became Count of the Holy Roman Empire and ran the government of Bavaria, first described a circulation system to explain these temperature observations. He suggested that cold water from north and south polar regions spreads on the bottom of the sea toward the equator, and this produces currents at the surface in the opposite directions. A further development of this idea was made by Emil von Lenz (1845), a German-Russian physicist, who noted that the thermocline was shallower near the equator than in the subtropics and proposed an upwelling of deep water into the surface layer near the equator to compensate for poleward flow of warm near surface water. He derived a conceptual model of the meridional overturning circulation in the Atlantic, which consisted of two circulation cells located symmetrically on either side of the equator. A schematic summarizing this circulation (Fig. 2) was published later by Spiess (1928) and more recently by Wüst (1968) and Mills (2005), who discussed early investigations of the meridional overturning circulation. The arrows in Figure 2 summarize the inferred direction of flow based on the temperature measurements. A curiosity is the way the arrows in the upper kilometer spiral into implied convergence zones centered near $700 \mathrm{~m}$ and $40^{\circ} \mathrm{N}$ and $40^{\circ} \mathrm{S}$. Implicit in this schematic is the formation of equal amounts of cold water in the north and south polar regions and a lack of inter-hemispheric exchange.

This early schematic based on the ideas of Lenz and others (see Warren, 1981) (Fig. 2) shows a very different perception of the Atlantic overturning circulation from what we know today. Our present perception of the overturning circulation (or thermohaline circulation as it is sometimes known) consists of a system of horizontal and vertical currents associated primarily with the formation of cold North Atlantic Deep Water in the North Atlantic, the southward flow of deep water away from the source regions and across the equator, and the northward flow of warm upper layer water back across the equator. Part of the deep water is further cooled in the Antarctic forming Antarctic 
Bottom Water, which spreads northward into the Atlantic, Indian and Pacific Oceans. The overturning circulation is a complicated system of currents driven by winds, by buoyancy forcing through evaporation, precipitation, heating, and cooling, and by mixing due to winds and tides. Knowledge of it developed slowly as subsurface temperature and salinity began to be accurately measured and the values accumulated into usable data sets. Perfecting instruments to make accurate measurements took a long time. Good historical reviews have been written by Wüst (1968), Deacon (1971), Reid (1981), Warren (1981, 2006), Mills (2005) and Peterson et al. (1996).

\subsection{Schott 1902}

The earliest schematics of the Atlantic meridional overturning circulation were developed by German oceanographers. The first was shown by Gerhard Schott (1902) based on the Valdivia Expedition (1898-1899) (Fig. 3). Two almost-symmetric circulation cells in the upper $2000 \mathrm{~m}$ are centered near a depth around $500 \mathrm{~m}$. Some deeper arrows at depths of 2000-3000 m extend northward from $60^{\circ} \mathrm{S}$ to $30^{\circ} \mathrm{N}$, colliding with southward arrows located north of around $30^{\circ} \mathrm{N}$. The northward flow near $2500 \mathrm{~m}$ is in an opposite direction to later findings of deep water crossing the equator from the north. In this and many other schematic circulation diagrams arrows indicate the direction of flow, thought to be ocean-wide, inferred from temperature, salinity, and density measurements. It was only much later that subsurface velocities were directly measured accurately enough to provide realistic mean velocities, and these were mainly limited to regions of swift boundary currents.

\subsection{Brennecke 1909, 1921}

Two longitudinal hydrographic sections were accomplished by Wilhelm Brennecke through the whole Atlantic aboard the Planet during 1906-1907 and the Deutschland during 1911-1912. In a 1909 schematic through the eastern Atlantic Brennecke sketched two symmetric circulation cells with upwelling near the equator and two nearlysymmetrical gyres at the surface (Brennecke, 1909) (Fig. 4). It is interesting that these 
first two schematics (Schott, 1902; Brennecke, 1909) were somewhat similar to the Lenz conceptual model in spite of the discoveries of the British Challenger Expedition in 18721876. Analysis of the Challenger data by Buchanan (Tizard et al., 1885) and Buchan (1895) (see Wüst, 1968; Warren, 1981) suggested a northward spreading of low salinity intermediate water near $800 \mathrm{~m}$ from high southern latitudes into the North Atlantic as far as $25^{\circ} \mathrm{N}$. Below this was higher salinity deep water at depths of $2000 \mathrm{~m}$ (and greater) spreading from $30^{\circ}-40^{\circ} \mathrm{N}$ southward across the equator. Only at the surface in Fig. 4 did arrows (based on ship drifts) indicate a northward inter-hemispheric flow.

With the Deutchland cruise Brennecke (1921) found additional details of the low salinity intermediate water and higher salinity deep water. In his 1921 schematic, mainly through the western Atlantic, he showed for the first time a picture of inter-hemispheric overturning circulation in the Atlantic that begins to look more realistic based on later studies (Fig. 5). Arrows in the intermediate water near $1000 \mathrm{~m}$ depth extend from the Antarctic region northward across the equator to $25^{\circ} \mathrm{N}$. Arrows in the deep water at depths of 1500-3300 m extend southward across the equator to $45^{\circ} \mathrm{S}$, and arrows in the bottom water $(>3300 \mathrm{~m})$ extend northward to around $20^{\circ} \mathrm{N}$. Two almost-symmetric circulation cells are retained in the upper $1000 \mathrm{~m}$, but they are displaced to the north, which causes the northward pointing arrows at $1000 \mathrm{~m}$ to cross the equator. Brennecke added some dashed vertical arrows near the equator at depths of 1000-3000 m perhaps a remnant of the Lenz idea of equatorial upwelling.

\subsection{Merz 1925}

In preparation for the planning of the Meteor expedition survey, Merz and Wüst (1922) pieced together the best hydrographic data available to construct a section through the eastern Atlantic north of the equator and western Atlantic south of the equator. Based on these sections Merz (1925) constructed a circulation schematic along $30^{\circ} \mathrm{W}$ showing arrows superimposed on salinity contours that for the first time clearly shows a good portrayal of the Atlantic inter-hemispheric overturning circulation, which was thought to be fairly uniform across the ocean (Fig. 6). Clearly apparent is the northward spreading of relatively fresh intermediate water and the southward spreading of relatively salty deep 
water. Starting at the surface in the North one can follow arrows southward at depths of $1000-4000 \mathrm{~m}$ across the equator and then up into the upper layer in the south where they are linked to arrows going north in the upper $1000 \mathrm{~m}$. Also apparent for the first time is a deeper overturning cell centered in the Antarctic region with some deep water from the North Atlantic descending near Antarctica into bottom water and spreading northward to the equator. The Merz (1925) schematic shows an inter-hemispheric conveyor-belt-like Atlantic circulation scheme in a vertical section. This schematic is very similar to those based on the later Meteor data, although the Meteor expedition provided a muchimproved sampling throughout the South Atlantic and a much clearer picture of the basin-wide circulation.

Both the Brennecke (1921) and the Merz (1925) schematics are based on the idea that subsurface water is formed at the sea surface and flows along tongue-like layers in the ocean that retain distinctive temperature, salinity, and density characteristics over long distances. The spreading of water along these tongues is illustrated by the arrows inferred from the temperature, salinity, and density distributions. This idea was further developed and exploited in the analysis of the Meteor Expedition data.

\subsection{Meteor Expedition, Wüst 1949, 1957}

The German Atlantic expedition of the Research Vessel Meteor during 1925-1927 has become famous for the high quality of the data and the superior resulting scientific reports. Alfred Merz was the scientific leader, but he died a few months after the expedition began. Captain Fritz Spiess of the Meteor took over scientific leadership of the expedition, and Merz's student, Georg Wüst, became leader of the oceanography studies. Reports and schematics based on the Meteor expedition and other stations clearly revealed features of what has become known as the Atlantic meridional overturning circulation-North Atlantic Deep Water (NADW) flowing southward in three identifiable layers, Subantarctic Intermediate Water plus surface water (and Antarctic Bottom Water) flowing northward (Wüst, 1935; Albert Defant, 1941). Clearly apparent on a vertical section through the western Atlantic based on data obtained aboard the Meteor, aboard the Woods Hole Oceanographic Institution (WHOI) Research Vessel 
Atlantis and a few other ships (Armauer Hansen, Carnegie, Dana, Discovery, Michael Sars) are tongues or cores of intermediate, deep, and bottom water with their inferred flow directions shown by arrows and the distribution of water properties like salinity and oxygen (Fig. 7, after Wüst, 1949). Maps of water properties and geostrophic velocity traced these tongues meridionally through the Atlantic to their general source regions and documented for the first time that their spreading is concentrated in western boundary currents (Figs. 8-9, after Wüst, 1957). In addition the salinity maximum layer, which originates at the surface in the South Atlantic near $15^{\circ} \mathrm{S}$ due to excess evaporation there, was traced at a depth of near $100 \mathrm{~m}$ northwestward across the equator and into the Caribbean (Defant, 1936). This indicated that virtually the whole upper layer, everything above NADW including the intermediate water, salinity maximum layer, and surface water (shown by ship drift velocities) crossed the equator as part of the overturning circulation. The results of the Meteor expedition along with additional cruise data were included in many publications and textbooks (for example by A. Defant, G. Dietrich, G. Neumann, G. Neumann and W. J. Pierson, W. S. von Arx) in the 1960's and since, which helped to promote an understanding of the Atlantic circulation. Later translations of Spiess (1928), Wüst (1935) and Defant (1936) in the period 1978-1985 made it easier for English readers to learn more about the remarkable results of the Meteor expedition.

The flow field of the eastern regions of the Atlantic was difficult to infer from the weak property gradients and slow speeds, but the general implication was a gradual southward spreading of NADW through the Atlantic in a direction away from its northern source region (Fig. 8). Some eastward protrusions from the core layers in the western Atlantic suggested the possibility of eastward flow near the equator and at other places in the South Atlantic, but turbulent lateral mixing could have also have accomplished this distribution of properties.

\subsection{Stommel 1957, 1958}

In 1957 Henry Stommel of WHOI revolutionized the concept of the Atlantic overturning circulation when he developed new ideas about deep circulation of the Atlantic and published three very influential schematics of the Atlantic circulation 
(Stommel, 1957, 1958a). One of these (Fig.10a) shows a three-dimensional schematic "internal mode" circulation of the Atlantic illustrating that the sinking of surface water in the north is connected to upwelling of deep water in the south by narrow western boundary currents in each level. Both sinking and upwelling occur in relatively small regions. The internal mode circulation (Fig. 10a) is the first three-dimensional schematic to clearly show a continuous conveyor-belt-like meridional overturning circulation through the Atlantic. In Fig. 10b Stommel indicated a schematic wind-driven circulation in the upper layer and in Fig. 10c a superposition of the two showing a return flow in the upper layer consisting of a merger of both wind-driven and internal mode circulations.

In a second figure (Fig. 11) Stommel showed the schematic circulation in the upper and lower layers of a more realistic Atlantic. Figure 11, which also appeared in Stommel's (1958b) book "The Gulf Stream," illustrates how the upper layer of the meridional overturning circulation (internal mode) merges with the wind-driven gyre flow, augmenting the wind-driven Benguela Current and Gulf Stream and opposing the Brazil Current. A narrow deep western boundary current flows southward underneath and counter to the Gulf Stream and North Brazil Current. This figure continues the idea of upwelling occurring in a limited region in the Antarctic Circumpolar Current. Figure 11 was a very influential conceptual schematic that illustrated how the Atlantic overturning circulation coexists with the wind-driven flow based on a straightforward linear superposition.

The third schematic (Fig.12) illustrates Stommel's (1958a) idea that since deep cold water upwells into warmer thermocline water above in order to balance the downward turbulent diffusion of heat then the deep water in the ocean interior must move poleward to conserve potential vorticity. Instead of moving southward through the interior of the North Atlantic, as had generally been assumed, NADW must move, paradoxically, northward toward its source. Swift narrow western boundary currents would be needed as conduits to balance the poleward interior flows and to carry source water southward. Expanding on this idea Stommel drew a schematic showing for the first time the interconnected deep flow of the oceans including the Indian and Pacific (Fig. 12). Unlike his two earlier schematics upwelling was assumed to occur uniformly throughout the oceans. The northern Pacific Ocean and northern Indian Ocean have no deep-water 
formation sites like the Atlantic, so that deep water from the North Atlantic and the Weddell Sea formation sites (each specified to be $20 \mathrm{~Sv}$ ) enters these oceans from the south in deep western boundary currents. Some deep flow continues eastward in the Antarctic Circumpolar Current and passes back into the Atlantic through the Drake Passage south of South America. This figure was not meant to represent the real ocean flow field because the real ocean has complicated sea floor topography including major ridge systems, which constrain the deep flow. Instead it was meant to give a general idea of what the deep flow might look like in the absence of these sea floor features and with uniform upwelling.

Stommel's idea of narrow western boundary currents and poleward interior flows was confirmed with some illustrative laboratory experiments (Stommel et al., 1958) and a deep western boundary current was confirmed in the North Atlantic by subsurface float measurements off South Carolina (Swallow and Worthington, 1961). The float measurements extended the earlier Meteor results, which had showed a western boundary current in the South Atlantic. The sluggish interior poleward flows resulting from the uniform upwelling were too small to measure despite attempts to do so. The ocean was found to be populated by intense mesoscale eddies and zonal currents, which make the mean meridional flow almost impossible to measure accurately.

In order to evaluate Stommel's (1958a) ideas and to help understand how lateral mixing might help determine the distribution of water characteristics like salinity and oxygen, Kuo and Veronis (1973) modeled an idealized ocean that consisted of rectangular ocean basins connected in the south, deep western boundary currents, and poleward interior flows. The model provided a fairly realistic distribution of oxygen content when suitable mixing was included. A good summary map was included of the global distribution of observed oxygen at a depth of $4 \mathrm{~km}$. The results of the study tended to validate Stommel's ideas of deep circulation and provided help in interpreting maps of water properties of the real ocean.

Stommel did not create a schematic of the upper layer return flow of the global ocean that would have resulted from the upwelling out of the deep layer, a global extension of Figure 11a. Although it was obvious that the water upwelled into the upper layer of the Pacific and Indian Ocean must return to the Atlantic around either southern 
Africa or South America or around both, the relative amounts of transport of the two routes was poorly known.

\section{Global ocean circulation}

\subsection{Broecker and Peng 1982}

The first two-layer schematic of a global overturning circulation was published by Wallace Broecker of the Lamont-Doherty Geological Observatory of Columbia University and Tsung-Hung Peng of the Oak Ridge National Laboratory in 1982 (Fig. 13), and these authors first suggested an analogy to a "large conveyor belt" when referring to their fun house conceptual circulation model. The lower panel of Figure 13 shows a vertical section with a conveyor-belt-like circulation with streamlines passing through the Atlantic, Indian and Pacific Oceans. Broecker and Peng's (1982) deep circulation scheme (top panel) looks rather similar to the Kuo and Veronis (1973) configuration of rectangular ocean basins and circulation except that not all of Broecker and Peng's deep interior flows are poleward. There are distributed upwelling sites, multiple offshoots in all three oceans, and a "recooling" located near the southernmost Atlantic near Antarctica. The deep-water path lies along the western boundaries of the Atlantic, Indian and Pacific, a pattern similar to one shown by Stommel (Fig. 11). All of the schematic upper layer return flow to the Atlantic is around southern Africa.

\subsection{Gordon 1986}

A more realistic schematic of the global overturning circulation was published by Arnold Gordon (1986) of the Lamont-Doherty Geological Observatory entitled "Global structure of the thermohaline circulation cell associated with NADW production" (Fig. 14). Figure 14 shows the Gulf Stream and Agulhas Current (the part that does not retroflect) as well as locations of deep-water formation in the North Atlantic and upwellings throughout the ocean basins. For the first time routes and transports of the return flow from the Pacific and Indian Oceans were clearly specified. The volume 
transports of major parts of the circulation are listed as $20 \mathrm{~Sv}\left(1 \mathrm{Sverdrup}(\mathrm{Sv})=10^{6}\right.$

$\mathrm{m}^{3} / \mathrm{sec}$ ) for the NADW in the North Atlantic, $8.5 \mathrm{~Sv}$ passing through the Indonesian Seas to the Indian Ocean, and 13.5 Sv returning to the Atlantic as Agulhas leakage. Gordon assumed that the cold-water route from the Drake Passage directly into the Atlantic overturning circulation was insignificant, although he mentioned that it could perhaps amount to around $3 \mathrm{~Sv}$. Therefore, virtually all the upper layer flow in compensation for the formation of NADW passes from the Indian Ocean around southern Africa into the Atlantic. In defense of this he quotes his measurement of $14 \mathrm{~Sv}$ entering the South Atlantic around an Agulhas Current ring (Gordon, 1985). Gordon's (1986) schematic circulation diagram (Fig. 14) looks conveyor-belt-like in the sense of a global band of arrows indicating deep water flow feeding from the Atlantic into the Indian and Pacific and a band of upper layer arrows returning to the Atlantic, but he did not use the conveyor belt analogy.

\subsection{Broecker 1987}

A schematic diagram entitled "Great Ocean Conveyor Belt" was published as an illustration in an article written by Broecker (1987) that appeared in Natural History (Fig. 15). It was designed by a magazine illustrator, Joe Le Monnier, to be a simple cartoon to illustrate the global ocean's meridional overturning circulation and the northward heat flux in the Atlantic caused in part by the wintertime formation of NADW. The conveyor is similar to Gordon's (1986) circulation scheme but has been simplified and made continuous through the oceans. Broecker's 1987 ocean conveyor is wide, colored, and quite visually striking.

Figure 15 shows a cold and salty deep current (blue) flowing southward through the mid-Atlantic, eastward in the Circumpolar Current region, and dividing into two deep currents that enter the Indian and Pacific Oceans. The deep currents upwell into warm shallow currents (red) that merge together in the Indian Ocean, flow around southern Africa and northward through the Atlantic. In the northern North Atlantic sea-to-air heat transfer causes the shallow current to become denser and to descend into the cold and salty deep current. The schematic's great strength (some would say great weakness) is its 
simple and attractive representation of very complicated currents, complicated physical processes, and complicated atmosphere-ocean interactions. Someone who knows little oceanography can easily grasp the concept of a three-dimensional, interconnected, global ocean circulation and the northward heat flux caused by the difference between warm water going north and cold water going south in the Atlantic. Heat is gained as the upper layer flows northward through the Atlantic tropics and heat is released in the northern North Atlantic as water is cooled by the atmosphere in winter to form deep water.

This simple diagram omits many very important aspects of the circulation. Some of its limitations are: It shows the sinking and upwelling in small areas; the oceanic upwelling is thought to be widespread. It omits recycling of NADW around Antarctica to become Antarctic Bottom Water. It suggests southward heat flux in the North Pacific. It wildly oversimplifies horizontal flow fields, omitting ocean gyres, western boundary currents, the Circumpolar Current and flow through the Drake Passage. It implies steady currents, but the ocean has strong fluctuations at seasonal and other frequencies including intense ocean eddies. Many physical oceanographers refuse to use this schematic or the conveyor-belt concept because they believe it is a misleading oversimplification. However, the unifying conceptual picture shown in the schematic has had wide popular appeal and can be considered a metaphor for the real overturning circulation.

The schematic of the "Great Ocean Conveyor Belt" was adopted as a logo for the Global Research Initiative and has become widely reproduced. It was included in the Academy Award-winning documentary and the book about climate change by $\mathrm{Al}$ Gore entitled "An Inconvenient Truth" (Gore, 2006). A modified, more complicated, version of the schematic appears on the website of the Intergovernmental Panel On Climate Change (IPCC see www.ipcc.ch), which projects a very likely reduction in conveyor flow by the end of the century, perhaps on the order of $25 \%$ (Kerr, 2007). An on-line search of "ocean conveyor" using Google Images reveals that 68 of the first 100 conveyor schematics to be similar to Broecker's 1987 version, followed by 22 similar to the IPCC version, plus 4 others by E. Maier-Reimer, 4 by W. Schmitz and two others.

Broecker (1991) described the scientific background of his 1987 schematic in a follow up article, which mentions his idea that changes in the Atlantic ocean conveyor were responsible for the abrupt and large climatic changes experienced by the northern 
Atlantic basin during the last glacial period. Broecker (1991) also clarified that in reality and in contrast to Fig. 15 upwelling is widely spread with a large amount taking place in the Antarctic. To further clarify his views, he included another figure (not shown) with 10 $\mathrm{Sv}$ of return flow entering the Atlantic through the Drake Passage and only $5 \mathrm{~Sv}$ entering from the Indian Ocean around the tip of Africa (with $5 \mathrm{~Sv}$ through the Indonesian Seas). This newer figure thus disagrees with Gordon's 1986 and Broecker's 1987 schematics. The two very different views of the relative amounts of Indian Ocean water and Drake Passage water in the overturning circulation have been a long-standing controversy, which continues even today. Good reviews of the subject are given by Schmitz (1995, 1996a,b), de Ruijter et al. (1999), Gordon (2001), and Lutjeharms (2006). The amount of Indian Ocean water leaking into the Atlantic and contributing to the overturning circulation, its distribution in depth, and its variability remain controversial, although some recent studies support a large leakage transport (Gordon, 2001; Sloyan and Rintoul, 2001; Mercier et al., 2003; Richardson, 2007). Measuring the transport is difficult because of the complexity of the highly energetic Agulhas retroflection region including Agulhas rings and cyclones, which translate into the Atlantic, contributing a major part of the Indian Ocean leakage. Two recent modeling studies that used a particle tracking technique to show pathways of the return flow concluded that virtually all the upper layer overturning circulation in the Atlantic enters as Indian Ocean leakage transport (Speich et al., 2001; Donners and Drijfhout, 2004).

In order to get the details of an overturning circulation schematic right requires knowing accurately how and where deep water is transformed into upper layer water and how the oceans are inter-connected, including how the upper layer flow returns to the Atlantic from the Indian and Pacific. These issues relevant to the overturning circulation are not well known and are being addressed by research programs. Recent knowledge has been summarized in a collection of papers describing results of the World Ocean Circulation Experiment (WOCE) published in "Ocean Circulation and Climate" (Siedler et al., 2001). A more recent summary of the global overturning circulation, based on inverse techniques, shows two main overturning cells—an upper cell ( $\sim 17 \mathrm{~Sv})$ concentrated in the Atlantic with sinking in the North Atlantic, upwelling in the Southern Ocean, and a lower cell ( $21 \mathrm{~Sv})$ with sinking around Antarctica and abyssal upwelling 
concentrated in the Indian and Pacific Oceans (Lumpkin and Speer, 2007). Another perspective is given by distributions of phosphate and oxygen in the deep water; these show that roughly half of the deep water in the Pacific and Indian Oceans originates in the northern Atlantic Ocean and half originates in the south near Antarctica (Broecker, personal communication, 2007). A few other smaller circulation cells are also apparent in the study of Lumpkin and Speer. In their results the majority of NADW enters the lower cell and is transferred into denser water classes, which subsequently flow northward into the deep Atlantic, Indian and Pacific Oceans. The linkages between the cells are illustrated with a colored schematic showing vertical sections through the different oceans and transports including error estimates of key circulation features of each ocean. The Atlantic part of the lower cell was shown in Fig. 6 (Merz, 1925) and Fig. 7 (Wüst, 1949). This new study and others like it reveals some of the complications of the global overturning circulation and points out some of the limitations of our understanding of it and limitations of the available data.

\subsection{Gordon 1991}

Trying to accurately show details of the global ocean circulation with schematics can lead them to become very complicated especially those in a plan view. A very useful circulation diagram was developed by Gordon (1991) showing a three-dimensional view of the global overturning circulation (Fig. 16). Vertical sections through the Atlantic, Indian and Pacific Oceans connect with the Southern Ocean. Vertical water motions, which are difficult to show on plan views, are clearly illustrated in the vertical sections. This figure is the first such three-dimensional global overturning schematic and illustrates a complicated system of flows in the ocean including the global structure of the upper and lower overturning cells and connections. William Schmitz (1996a,b) of the Woods Hole Oceanographic Institution colored and revised this figure as part of his comprehensive review of the global ocean circulation and included a later version of the figure on the cover of his report (Schmitz, 1996b). This later version was also included in an article by Clarke et al. (2001) in the WOCE book (Siedler et al. 2001). A more recent schematic like this is shown by Lumpkin and Speer (2007). 
Further developments of global overturning schematics were made by Schmitz (1995, 1996a,b) who summarized various ocean observations and circulation schemes and created several of his own schematics, including some with two, three and four layers in the vertical to represent the different layers in the ocean. The simple two-layer overturning circulation schematic is easy to see and understand, the three- and four-layer schematics present more information about pathways, transports, vertical movements, and water conversions but can be significantly more complicated, difficult enough that only a dedicated reader will try to understand the patterns. A three-layer schematic of the upper layer (Fig.17) (Schmitz, 1996b) shows the complex global overturning circulation including bottom, deep, and upper layer water, and illustrates important aspects ignored in two-layer conveyor schematics such as more complicated circulations and water transformations in the various basins. Schmitz increased the value of many of his schematics, including Fig. 17, by specifying the transport of various circulation features. In his 1995 schematics, Schmitz indicated a low Agulhas leakage transport of 4 Sv. In his $1996 \mathrm{~b}$ revision, he increased the leakage to $7 \mathrm{~Sv}$ in order to reflect an equipartition between Drake Passage and Indian Ocean sources. Improved measurements today are leading to changes in the details of these schematics including an increase of Agulhas leakage transport. However, new measurements will not change the 1987 conveyor belt schematic because the general idea it portrays has not changed significantly.

Schmitz (1996a) included numerous circulation schemes of the North Atlantic, several of which illustrate paths of the warm-to-cold transformations in the northern North Atlantic. Most of these schematics are plan views, but one attributed to Mike McCartney and Ruth Curry is a colored vertical section showing the complicated connections between different layers in the vertical, an update of the northern part of Gordon's (1991) Atlantic section. A novel feature is a prominent schematic eggbeater to represent deep ocean mixing.

Two other global schematics were helpful in developing ideas of the upper layer return flow. Gordon et al. (1992) divided the return flow into two layers and indicated the 
transport of each layer, including $15 \mathrm{~Sv}$ of Agulhas leakage, 9 of which continues northward in the overturning circulation. Sloyan and Rintoul (2001) in a somewhat similar diagram showed that of $14 \mathrm{~Sv}$ in the overturning circulation in the Atlantic $10 \mathrm{~Sv}$ is derived from Agulhas water. These schematics illustrate the concept that most of the Drake Passage water that eventually flows northward in the Atlantic overturning circulation first continues eastward through the Atlantic, loops into the Indian and Pacific, and then returns westward around the tip of Africa after having been significantly modified by air-sea interactions and mixing.

\subsection{IPCC 2001}

The Intergovernmental Panel of Climate Change report included a map entitled "Great ocean conveyor belt" that shows some new features added to a Broecker-like conveyor (Fig. 18). Two sites of "heat release to atmosphere" are located in the northern North Atlantic and a third in the Weddell Sea. Water from the Weddell Sea site joins the deep water from the Atlantic. A continuous global upper layer Circumpolar Current has a branch flowing northward in the Atlantic and is joined by a branch from the Indian Ocean. One curiosity (mistake?) is that the cold saline deep current (blue) appears to twice magically flow over the top of the warm surface current (orange) in the Pacific (http://www.ipcc.ch, figure 4-2 of the 2001 Synthesis Report under "Graphics"). This figure including a revised version (warm over cold) under "Publications" is widely used as an illustration of the meridional overturning circulation. A limitation is that transports of the various current branches are not specified.

A recent schematic (not shown) by Rick Lumpkin (personal communication, 2006) of the NOAA Atlantic Oceanographic and Meteorological Laboratory illustrates some new features of the global ocean circulation, including the flow of Pacific water westward around Tasmania into the Indian Ocean (an addition to the flow through the Indonesian Seas). A novel aspect is the inclusion of schematic anticyclonic eddies, illustrating that at some places the Atlantic overturning circulation is primarily in the form of very large, translating, coherent eddies. The eddies are shed by the Agulhas retroflection south of Africa, by the deep western boundary current south of the equator off Brazil and by the 
North Brazil Current retroflection off northeastern South America. The Atlantic part of this schematic was included in "Charting the course for Ocean Science in the United States for the next decade," a 2007 report of the NSTC Joint Subcommittee on Ocean Science and Technology (http://ocean.ceq.gov/about/docs/orpp21607.pdf), and also by Stokstad (2007). An earlier schematic of the upper layer return flow that also included Agulhas Current rings was published by Gordon (2003). Refinements such as these are attempting a closer match to verisimilitude.

\section{Summary and conclusions}

The Great Ocean Conveyor Belt schematic published by Broecker (1987) is a metaphor for the global ocean overturning circulation. This schematic expresses some ideas that are generally believed to be true: 1) the upper layer water in the North Atlantic is cooled forming cold NADW, 2) NADW flows into the Southern Ocean, Indian Ocean, and Pacific Ocean as part of a three-dimensional global overturning circulation system, 3) the deep cold water is transformed into warmer upper layer water which returns from the Pacific and Indian Oceans to the Atlantic around southern Africa (controversial), and 4) the northward flow of warm upper layer water and southward flow of cold deep water in the Atlantic causes a northward heat flux through the Atlantic. The conveyor belt schematic does not reproduce the actual global circulation because it is much too complicated for a simple diagram, but the schematic has served well in providing a simple image that people can easily understand, despite its many inaccuracies and oversimplifications. Refinements of the schematic have been made to reflect some of the complexities of the overturning circulation, including a widespread version included in the 2001 IPCC report. The innovative schematics of W. Broecker, A. Gordon, and W. Schmitz have been very influential in helping people visualize aspects of the global overturning circulation. It is difficult to be quantitative about ocean circulation, but some of the most useful schematics have included transport estimates of circulation features. 


\section{Acknowledgements}

Colleen Hurter found numerous older journals and books, used in the study. Dave Gray scanned most of the figures used as illustrations. Wally Broecker and Arnold Gordon provided Figures 15 and 16. Jim Price and Bruce Warren gave some detailed constructive comments and suggestions on earlier versions of this paper.

\section{References}

Brennecke, W., 1909. Ozeanographie. Forschungsreise S.M.S. "Planet" 1906/07, 3, 153 pp.

Brennecke, W., 1921. Die ozeanographischen Arbeiten der Deutschen Antarktischen Expedition 1911-1912. Aus dem Archiv der Deutschen Seewarte 39:1, 216 pp.

Broecker, W.S., 1987. The biggest chill. Natural History Magazine 97, 74-82.

Broecker, W.S., 1991. The Great Ocean Conveyor. Oceanography 4(2), 79-89.

Broecker, W.S. Peng, T.-H., 1982. Tracers in the Sea. Eldigio Press, Palisades, New York, $690 \mathrm{pp}$.

Buchan, A., 1895. Report on oceanic circulation, based on the observations made on board H.M.S. Challenger, and other observations. In Report on the Scientific Results of the Voyage of the H.M.S. Challenger during the years 1873-76. A summary of the Scientific Results, Second Part, Appendix (Physics and Chemistry, Part VIII), 38 pp.

Clarke, A., Church, J. Gould, J., 2001. Ocean Processes and Climate Phenomena. In:

Siedler, G., Church, J., Gould, J. (Eds), Ocean Circulation and Climate: Observing and Medelling the Global Ocean. Academic Press, New York, pp. 11-30. 
Deacon, M., 1971. Scientists and the Sea 1650-1900: A Study of Marine Science. Academic Press, London and New York, 445 pp.

Defant, A., 1936. Schichtung und Zirkulation des Atlantischen Ozeans. Die Troposphäre. In Wissenschaftliche Ergebnisse der Deutschen Atlantischen Expedition auf dem Forschungs - und Vermessungsschiff "Meteor" 1925-1927, 6: $1^{\text {st }}$ Part, 3, Berlin, pp. 289411 pp. (The Troposphere: Scientific Results of the German Atlantic Expedition of the Research Vessel "Meteor" 1925-1927, Emery, W.J. (Ed.), 1981 Amerind, New Delhi, $113 \mathrm{pp}$.

Defant, A., 1941. Die absolute Topographie des physikalischen Meeresniveaus und der Drückflachen sowie die Wasserbewegungen im Raum des Atlantischen Ozeans. In Wissenschaftliche Ergebnisse der Deutschen Atlantischen Expedition auf dem Forschungs - und Vermessungsschiff "Meteor" 1925-27, 6:2 ${ }^{\text {nd }}$ Part, 1, Berlin, pp. 191260.

de Ruijter, W.P.M., Biastoch, A., Drijfhout, S.S., Lutjeharms, J.R.E., Matano, R.P., Pichevin, T., van Leeuwen, P.J., Weijer, W., 1999. Indian-Atlantic interocean exchange: Dynamics, estimation and impact. Journal of Geophysical Research 104 (C9), 20,88520,910 .

Donners, J., Drijfhout, S., 2004. The Lagrangian view of South Atlantic interocean exchange in a global ocean model compared with inverse model results. Journal of Physical Oceanography 34, 1019-1035.

Ellis, H., 1751. A letter to the Rev. Dr. Hales, F.R.S. from Captain Henry Ellis, F.R.S. dated Jan. 7, 1750-51, at Cape Monte Africa, Ship Earl of Halifax. Philosophical Transactions of the Royal Society of London 47, 211-214. 
Gordon, A.L., 1985. Indian-Atlantic transfer of thermocline water at the Agulhas retroflection. Science 227, 1030-1033.

Gordon, A.L., 1986. Interocean exchange of thermocline water. Journal of Geophysical Research 91(C4), 5037-5046.

Gordon, A., 1991. The role of thermohaline circulation in global climate change, in Lamont-Doherty Geological Observatory 1990 \& 1991 Report, Lamont-Doherty Geological Observatory of Columbia University, Palisades, New York, pp. 44-51.

Gordon, A.L., 2001. Interocean exchange. In: Siedler, G., Church, J., Gould, J. (Eds.), Ocean Circulation and Climate. Academic Press, London, pp. 303-314.

Gordon, A.L., 2003. The brawniest retroflection. Nature 421, 904-905.

Gordon, A.L., Weiss, R.F., Smethie, Jr., W.M., Warner, M.J., 1992. Thermocline and intermediate water communication between the South Atlantic and Indian Oceans. Journal of Geophysical Research 97 (C5), 7223-7240.

Gore, A., 2006. An Inconvenient Truth: the Planetary Emergency of Global Warming and What we can do About it. Rodale Press, Emmaus PA, 325 pp.

Kerr, R.A., 2007. Scientists Tell Policymakers We're All Warming the World. Science $15,754-757$.

Kuo, H.-H., Veronis, G., 1973. The use of oxygen as a test for an abyssal circulation model. Deep-Sea Research 20, 871-888.

Lenz, E., 1845. Bermerkungen über die Temperatur des Weltmeeres in verschiedenen Tiefen. Bulletin de la Classe Physico-Mathématique de l'Académie Impériale des Sciences de Saint-Pétersbourg 5, 67-74. 
Lumpkin, R., Speer, K., 2007. Global ocean meridional overturning. Journal of Physical Oceanography, in press.

Lutjeharms, J.R.E., 2006. The Agulhas Current. Springer, New York, 329 pp.

Mercier, H., Arhan, M., Lutjeharms, J.R.E., 2003. Upper-layer circulation in the eastern Equatorial and South Atlantic Ocean in January-March 1995. Deep-Sea Research Part I $50,863-887$.

Merz, A., 1925. Die Deutsche Atlantische Expedition auf dem Vermessungs- und Forschungsschiff "Meteor". 1. Bericht. Sitzungsberichte der Preussischen Akademie der Wissenschaften, Physikalische-Mathematische Klasse, Jahrgang 1925, 562-586.

Merz, A., Wüst, G., 1922. Die Atlantische Vertikalzirkulation. Zeitschrift der Gesellschaft für Erdkunde zu Berlin, Jahrgang 1922, 1-35.

Mills, E.L., 2005. From Discovery to discovery: the hydrography of the Southern Ocean, 1885-1937. Archives of natural history 32 (2), 246-264.

Peterson, R.G., Stramma, L., Kortum, G., 1996. Early Concepts and Charts of Ocean Circulation. Progress in Oceanography 37, 1-115.

Reid, J.L., 1981. On the Mid-Depth Circulation of the World Ocean. In: Warren, B.A., Wunsch, C. (Eds), Evolution of Physical Oceanography. MIT Press, Cambridge MA, pp. 70-110.

Rennell, J., 1832. An Investigation of the Currents of the Atlantic Ocean, and of Those Which Prevail between the Indian Ocean and the Atlantic, J.G.\&F. Rivington, London, $359 \mathrm{pp}$. 
Richardson, P.L., 2007. Agulhas leakage into the Atlantic estimated with subsurface floats and surface drifters. Deep-Sea Research Part I, in press.

Rumford, B., Count of, 1798. Of the propagation of heat in fluids. In Essays, Political, Economical and Philosophical. T. Caldwell and W. Davies, London, pp. 199-313. (Reprinted In: Collected Works of Count Rumford. Volume 1. The Nature of Heat, 1968. Brown, S.C. (Ed), Belknap Press of Harvard University Press, Cambridge MA, 1968, 507 pp, 117-284.)

Schmitz, Jr., W.J., 1995. On the interbasin-scale thermohaline circulation. Reviews of Geophysics 33(2), 151-173.

Schmitz, Jr., W.J., 1996a. On the World Ocean Circulation: Volume I, Some Global Features/North Atlantic Circulation. Woods Hole Oceanographic Institution Technical Report WHOI-96-03, 141 pp.

Schmitz, Jr., W.J., 1996b. On the World Ocean Circulation: Volume II, The Pacific and Indian Oceans/A Global Update. Woods Hole Oceanographic Institution Technical Report WHOI-96-08, 237 pp.

Schott. G., 1902. Oceanographie und maritime Meteorolgie. In Wissenschaftliche Ergebnisse der Deutschen Tiefsee-Expedition auf dem Dampfer "Valdivia" 1898-1899, $1,403 \mathrm{pp}$.

Siedler, G., Church, J., Gould, J. (Eds), 2001. Ocean Circulation and Climate: Observing and Modelling the Global Ocean. Academic Press, New York, 715 pp.

Sloyan, B.M., Rintoul, S.R., 2001. Circulation, renewal, and modification of Antarctic Mode and Intermediate Water. Journal of Physical Oceanography 31, 1005-1030. 
Speich, S., Blanke, B., Madec, G., 2001. Warm and cold water routes of an O.G.C.M. thermohaline conveyor belt. Geophysical Research Letters 28 (2), 311-314.

Spiess, F., 1928. Die Meteor-Fahrt. Forschungen und Ergebnisse der Deutschen Atlantischen Expedition. 1925-1927. Dietrich Reimer. Berlin, 375 pp. (The Meteor Expedition, Scientific Results of the German Atlantic Expedition, 1925-1927. Emery, W.J., (Ed), 1985. Amerind Publishing, New Delhi, 429 pp.)

Stokstad, E., 2007. Ocean research gets a modest boost. Science 315, 585-586.

Stommel, H.M., 1957. A survey of ocean current theory. Deep-Sea Research 4, 149-184.

Stommel, H.M., 1958a. The abyssal circulation. Deep-Sea Research 5, 80-82.

Stommel, H.M., 1958b. The Gulf Stream: A Physical and Dynamical Description. University of California Press, Berkeley, 202 pp.

Stommel, H.M., Arons, A.B., Faller, A.J., 1958. Some examples of stationary planetary flow patterns in bounded basins. Tellus 10, 179-187.

Swallow, J.C., Worthington, L.V., 1961. An observation of a deep countercurrent in the western North Atlantic. Deep-Sea Research 8, 1-19.

Tizard, T.H., Mosely, H.N., Buchanan, J.Y., Murray, J., 1885. Report on the Scientific Results of the Voyage of the H.M.S. Challenger during the years 1873-76. Narrative of the Cruise of H.M.S. Challenger with a General Account of the Scientific Results of the Expedition, 1, Second Part, pp. 511-1110.

Warren, B.A., 1981. Deep Circulation of the World Ocean. In: Warren, B.A., Wunsch, C., (Eds), Evolution of Physical Oceanography. MIT Press, Cambridge MA, pp. 6-41. 
Warren, B.A., 2006. Historical Introduction, Oceanography of the General Circulation to the Middle of the Twentieth Century. In: Jochum, M., Murtugudde, R. (Eds.), Physical Oceanography Developments Since 1950. Springer, New York, pp.1-14.

Wüst, G., 1935. Schichtung und Zirkulation des Atlantischen Ozeans. Die Stratophäre. In Wissenschaftliche Ergebnisse der Deutschen Atlantischen Expedition auf dem Forschungs - und Vermessungsschiff "Meteor" 1925-1927, 6: $1^{\text {st }}$ Part, 2, Berlin, 180 pp. (The Stratosphere of the Atlantic Ocean, Emery, W.J., (Ed), 1978 Amerind, New Delhi, 112 pp.)

Wüst, G., 1949. Die Kreisläufe der atlantischen Wassermassen, ein neuer Versuch räumlicher Darstellung. Forschungen und Fortschritte 25, 285-289.

Wüst, G., 1957. Stromgeschwindigkeiten und Strommengen in den Tiefen des Atlantischen Ozeans unter besonderer Berücksichtigung des Tiefen- und Bodenwassers. Wissenschaftliche Ergebnisse der Deutschen Atlantischen Expedition auf dem Forschungs - und Vermessungsschiff "Meteor" 1925-1927, 6: 2nd Part, 6, Berlin, 180 pp.

Wüst, G., 1968. History of investigations of the longitudinal deep-sea circulation (18001922). Bulletin de l'Institut Océanographique, Monaco, Numéro Special 2, 109-120 pp.

\section{Figure captions}

Figure 1. Rennell's (1832) chart of the surface currents of the Atlantic Ocean based on early ship drift measurements as shown by Deacon (1971).

Figure 2. Meridional overturning circulation scheme of the Atlantic corresponding to the written conceptions of Lenz (1845) as shown by Spiess (1928). Two opposite symmetrical branches of the deep currents converge and rise towards the surface at the equator to balance poleward flow of near surface water. 
Figure 3. Meridional overturning circulation scheme shown by Schott (1902).

Figure 4. Block diagram illustrating the circulation scheme of the eastern Atlantic consisting of nearly-symmetrical vertical circulation cells with upwelling near the equator and nearly-symmetrical gyre circulations at the surface (Brennecke, 1909).

Figure 5. Meridional circulation scheme mainly along the western Atlantic (Brennecke, 1921).

Figure 6. Meridional circulation scheme along $30^{\circ} \mathrm{W}$ shown by Merz (1925). Arrows and contours of salinity clearly show an inter-hemispheric circulation consisting of northward spreading of intermediate water in about $800 \mathrm{~m}$ from $45^{\circ} \mathrm{S}$ to $20^{\circ} \mathrm{N}$ and the southward spreading of deep water at $1500-3500 \mathrm{~m}$ from $30^{\circ} \mathrm{N}$ to $55^{\circ} \mathrm{S}$.

Figure 7. Block diagram of surface currents, salinity contours and the meridional circulation along a section in the western Atlantic by Wüst (1949) based on the Meteor expedition and other hydrographic data (Wüst, 1935). Small numbers are geostrophic speeds in $\mathrm{cm} / \mathrm{sec}$. Dashed line is the boundary $\left(9^{\circ} \mathrm{C}\right)$ between warm and cold layers.

Figure 8. Spreading of the middle NADW in the core of a maximum of oxygen content at depths of 2000-3000 m (Wüst, 1935) and geostrophic current flow at a depth of $2000 \mathrm{~m}$ (Defant, 1941) as shown by Wüst (1957). The main southward spreading axis lies close to the western boundary.

Figure 9. Spreading of low salinity Subantarctic Intermediate Water in about 500-900 m (Wüst, 1935) and geostrophic current flow at a depth of $800 \mathrm{~m}$ (Defant, 1941) as shown by Wüst (1957). The main northward spreading axis lies close to the western boundary.

Figure 10. Schematic interpretation of the circulation in the Atlantic constructed by Stommel (1957) by superposing an internal mode associated with flow across a level 
surface $\mathrm{L}$ at mid-depth (a) and purely wind-driven circulation in the surface layers (b). The superposition of these two is shown in (c).

Figure 11. Schematic upper layer (a) and deep layer (b) circulation in the Atlantic including a superposition of the internal mode and wind-driven components as shown by Stommel (1957). Small circles indicate general regions of vertical motion connecting surface and deep layers.

Figure 12. Schematic of deep circulation of the world ocean according to Stommel (1958a). The circulation consists of poleward flows in the ocean interior and narrow swift western boundary currents connecting source regions in the North Atlantic and Antarctic to the interior flows.

Figure 13. First schematic of a global ocean conveyor belt as shown by Broecker and Peng (1982). Their caption states: "The upper diagram is an idealized map of the patterns of deep water flow (solid lines) and surface water flow (dashed lines). The large circles designate the sinking of NADW in the Norwegian Sea and the recooling of water along the perimeter of the Antarctic Continent; the shaded circles indicate the distributed upwelling which balances this deep water generation. The lower diagram is an idealized vertical section running from the North Atlantic to the North Pacific showing the major advective flow pattern (solid lines) and the rain of particles (wavy lines)."

Figure 14. Global structure of the thermohaline circulation cell associated with NADW production as shown by Gordon (1986). Gordon's caption states: "The warm water route, shown by solid arrows, marks the proposed path for return of upper layer water to the northern North Atlantic as is required to maintain continuity with the formation and export of NADW. The circled values are volume flux in $10^{6} \mathrm{~m}^{3} / \mathrm{sec}$, which are expected for uniform upwelling of NADW with a production rate of $20 \times 10^{6} \mathrm{~m}^{3} / \mathrm{sec}$. These values assume that the return within the cold water route, via the Drake Passage (dashed line), is of minor significance." 
Figure 15. The great ocean conveyor belt logo shown by Broecker (1987) as illustrated by Joe Le Monnier, Natural History Magazine.

Figure 16. A three-dimensional schematic of global interbasin flow with typical vertical meridional sections for each ocean and their connections in the Southern Ocean by Gordon (1991).

Figure 17. A three-layer schematic of the global interbasin circulation by Schmitz (1996b). Values in circles represent transport in Sverdrups. UPOCNW designates upper ocean water, a combination of upper layer water and intermediate water. This figure was included on the back cover of Schmitz' (1996b) report.

Figure 18. Schematic shown on the Intergovernmental Panel of Climate Change (IPCC) website (http://www.ipcc.ch, figure 4-2 of the 2001 Synthesis Report under "Graphics"). The caption for this figure on the website listed under "Publications" states: "Schematic illustration of the global circulation system in the world ocean consisting of major northsouth thermohaline circulation [THC] routes in each ocean basin joining in the Antarctic circumpolar circulation. Warm surface currents are connected in the few areas of deepwater formation in the high latitudes of the Atlantic and around Antarctica (blue), where the major ocean-to-atmosphere heat transfer occurs. This current system contributes substantially to the transport and redistribution of heat (e.g., the poleward flowing currents in the North Atlantic warm northwestern Europe by up to $10^{\circ} \mathrm{C}$ ). Model simulations indicate that the North Atlantic branch of this circulation system is particularly vulnerable to changes in atmospheric temperature and in the hydrological cycle. Such perturbations caused by global warming could disrupt the current system, which would have a strong impact on regional-to-hemispheric climate. Note that this is a schematic diagram and it does not give the exact locations of the water currents that form part of the THC." 


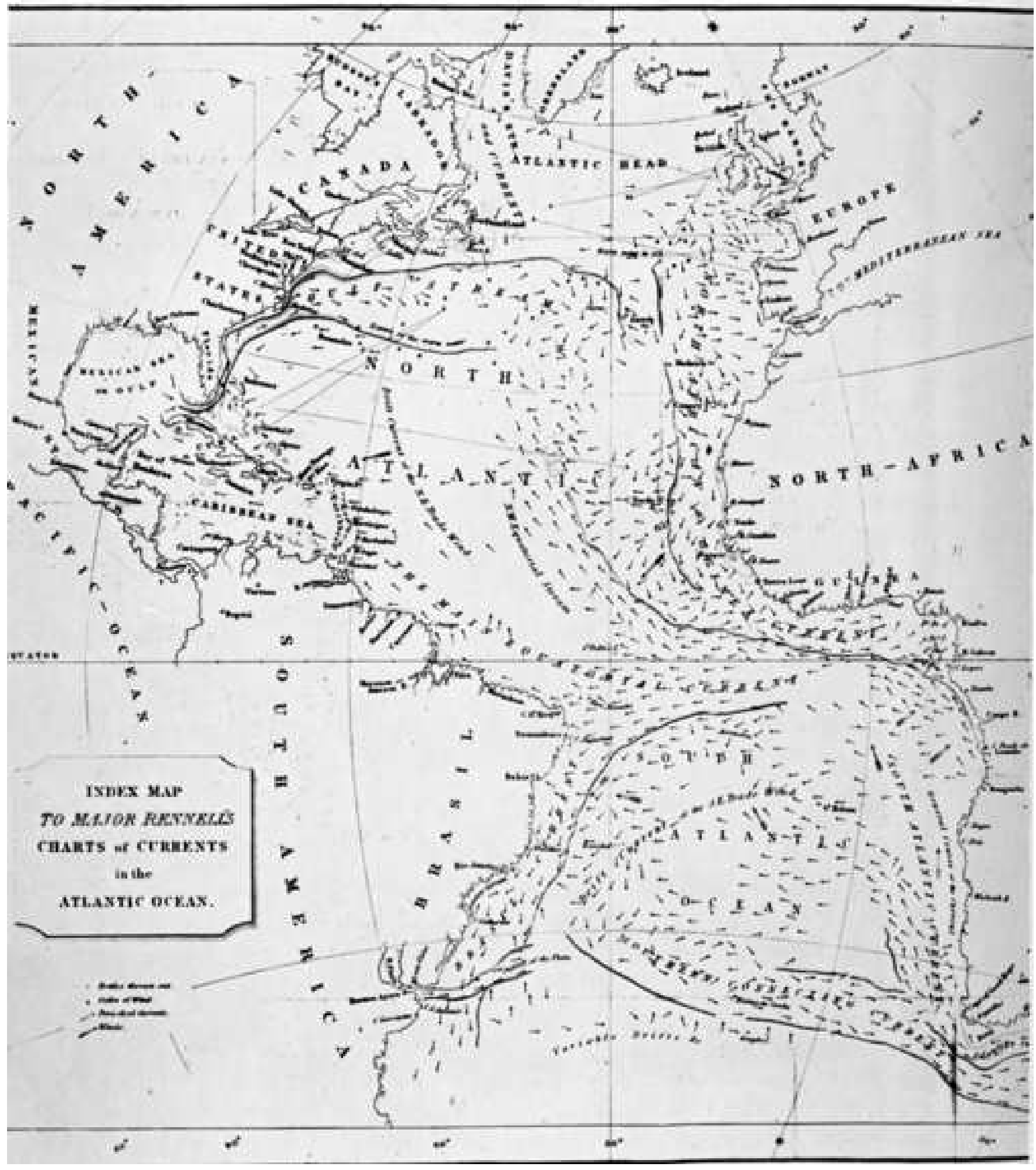


Figure 2

Click here to download high resolution image

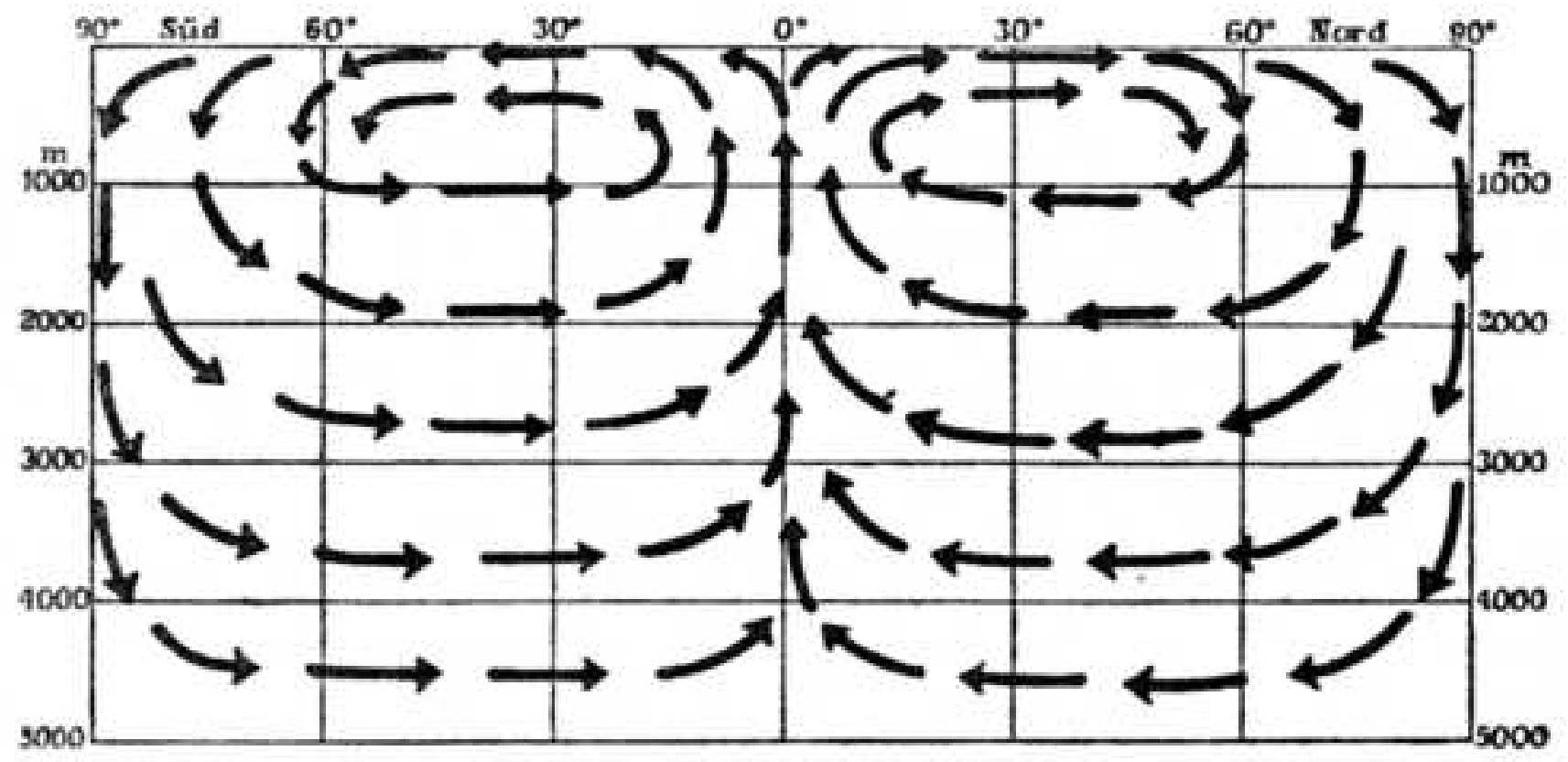


Click here to download high resolution image

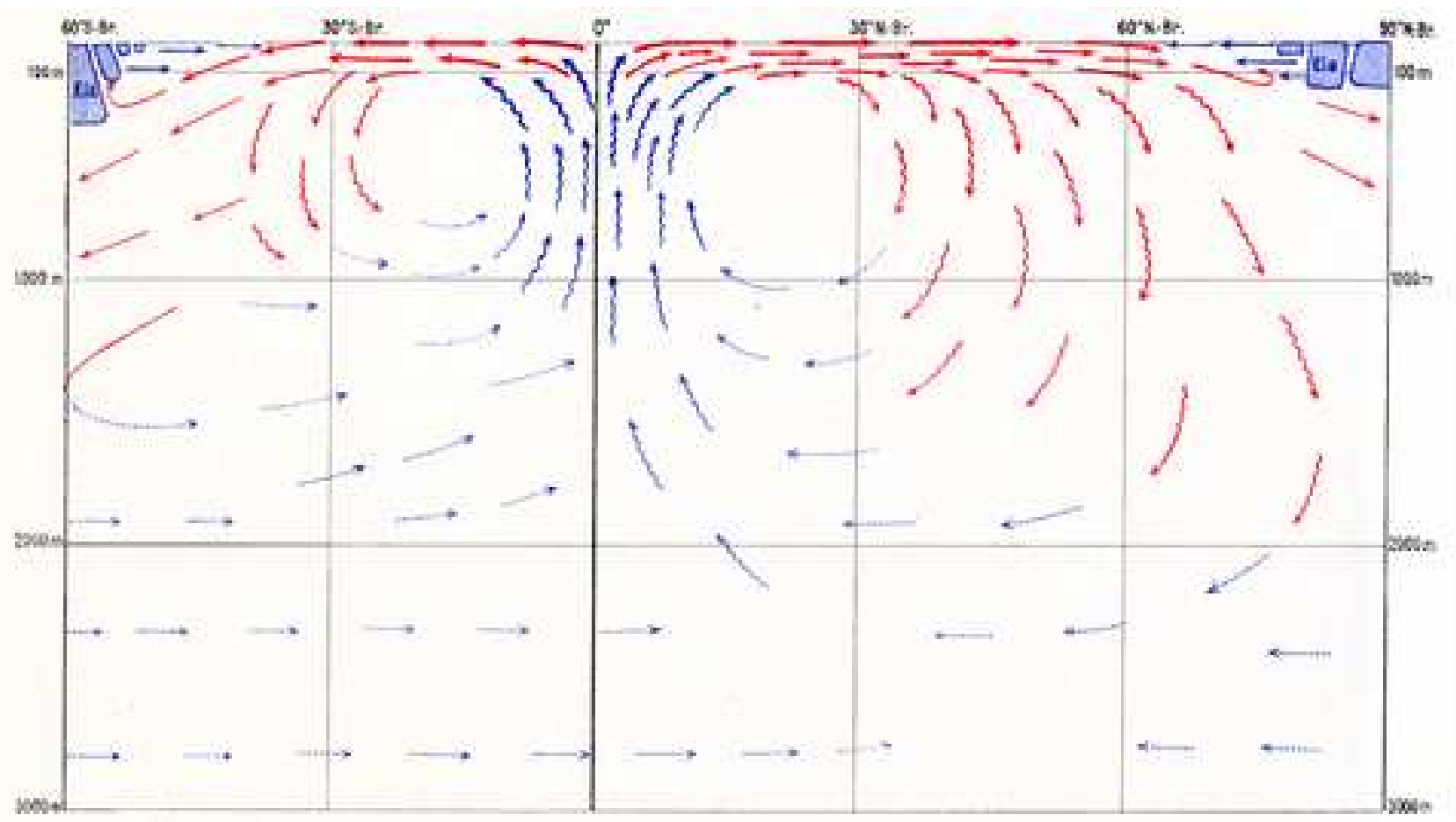


Figure 4
Click here to download high resolution image

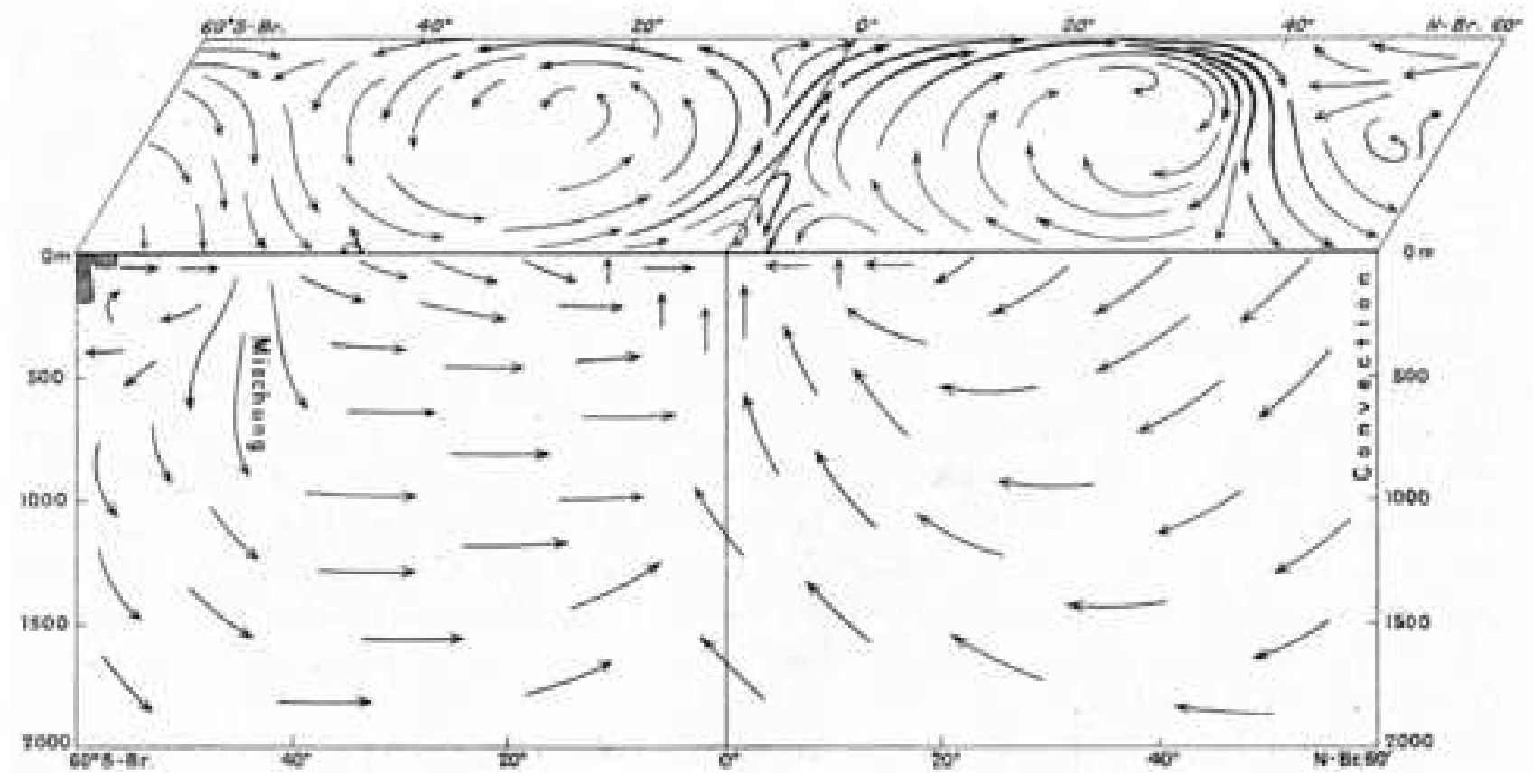


Figure 5

Click here to download high resolution image

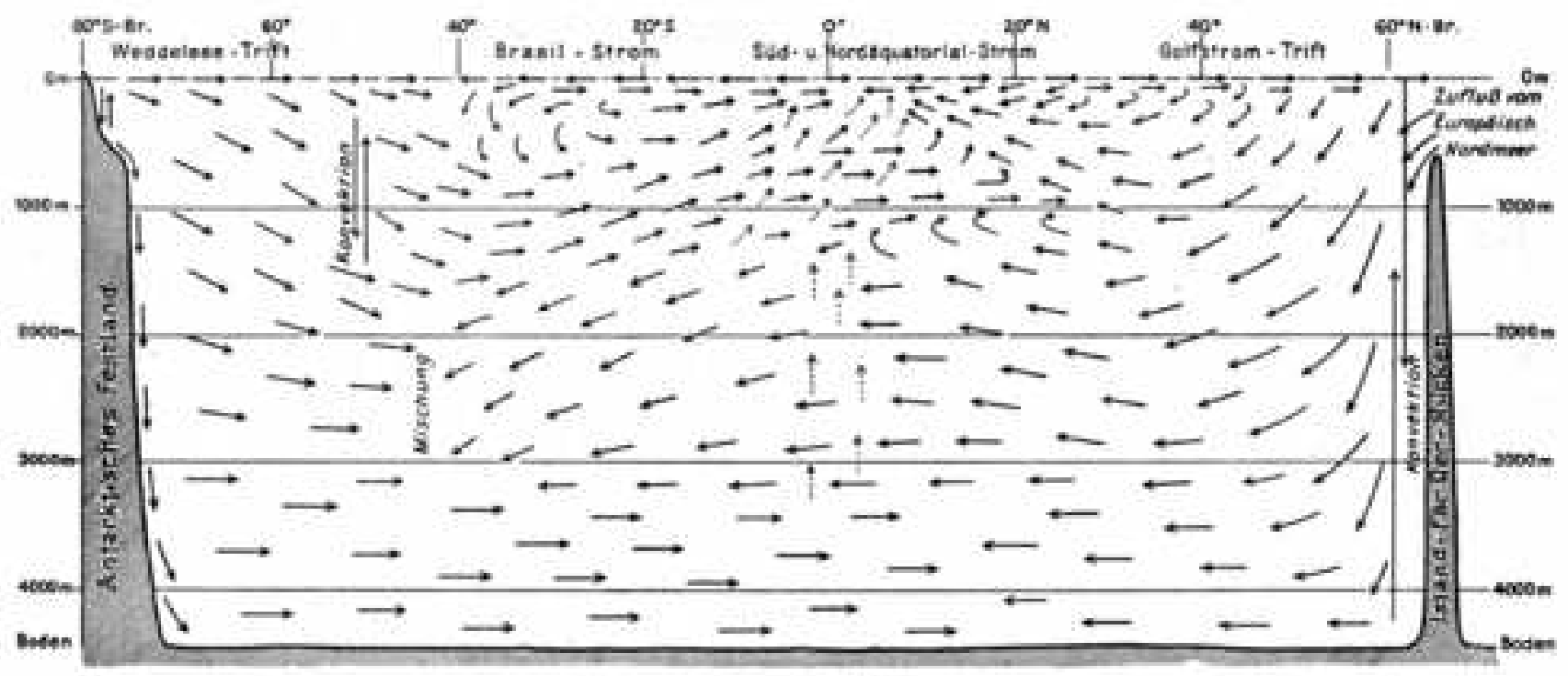

$\mathrm{L}+\mathrm{T}=1: 1500$ 
Figure 6

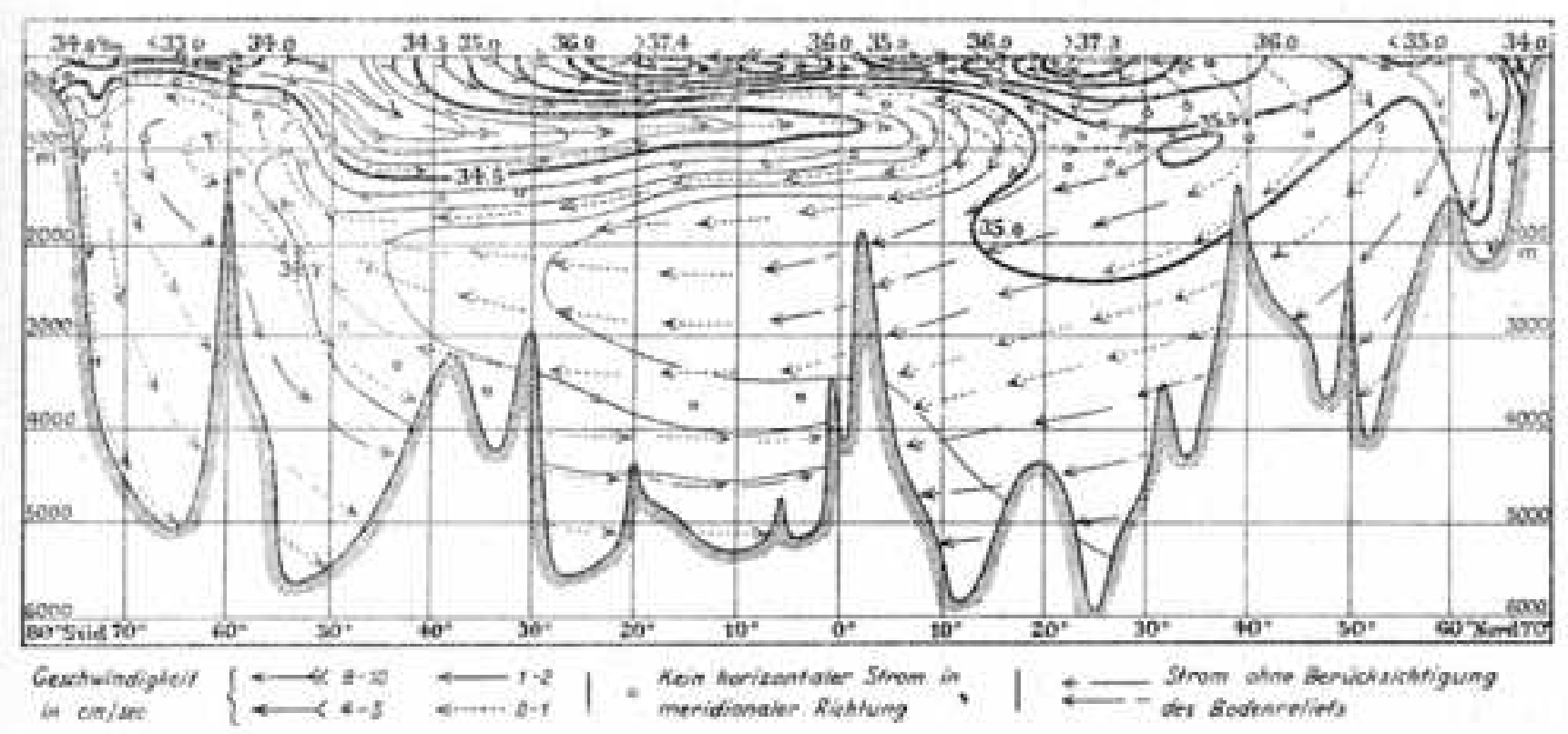

\section{Click here to download high resolution image}


Figure 7

Click here to download high resolution image

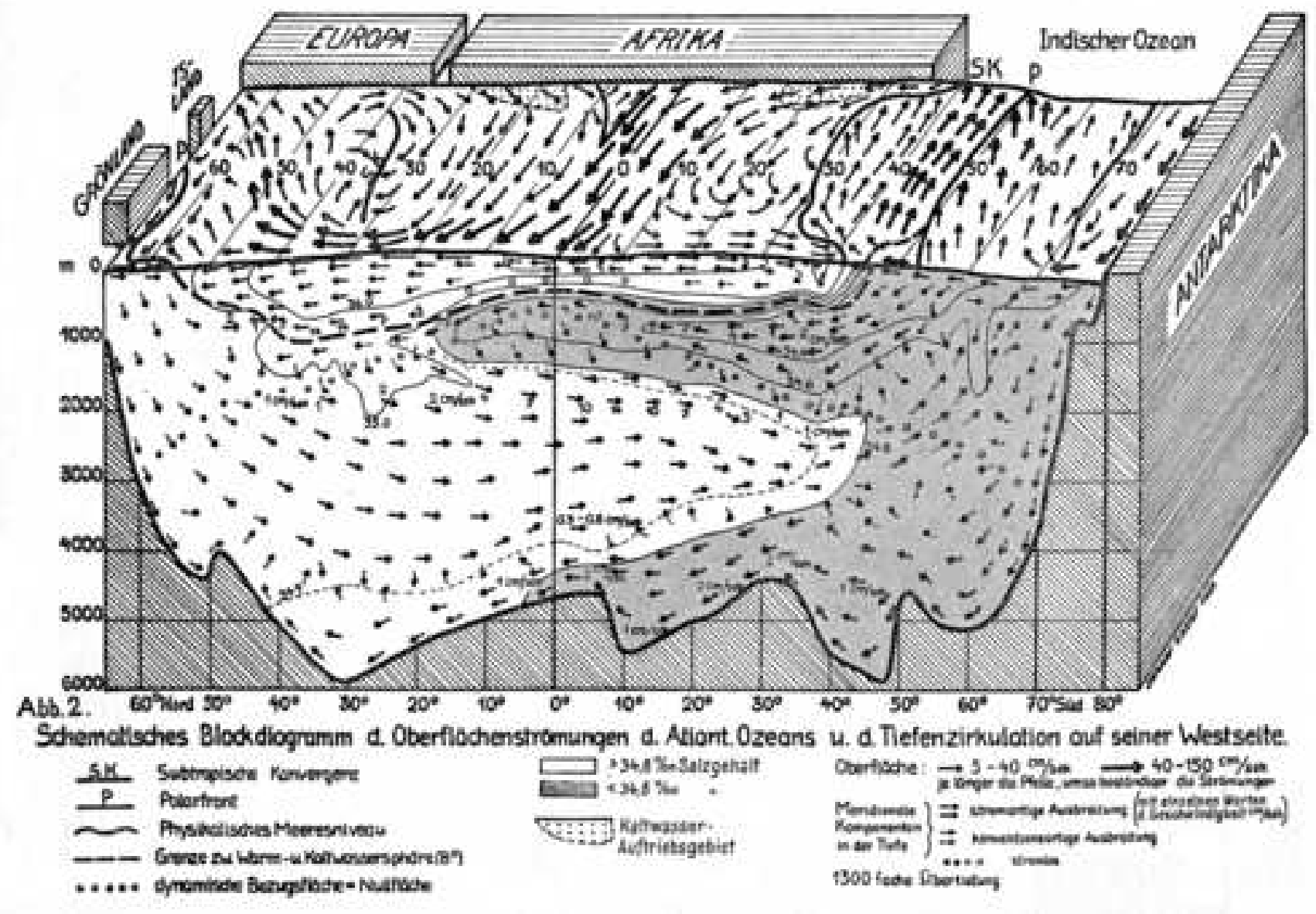


Figure 8

Click here to download high resolution image

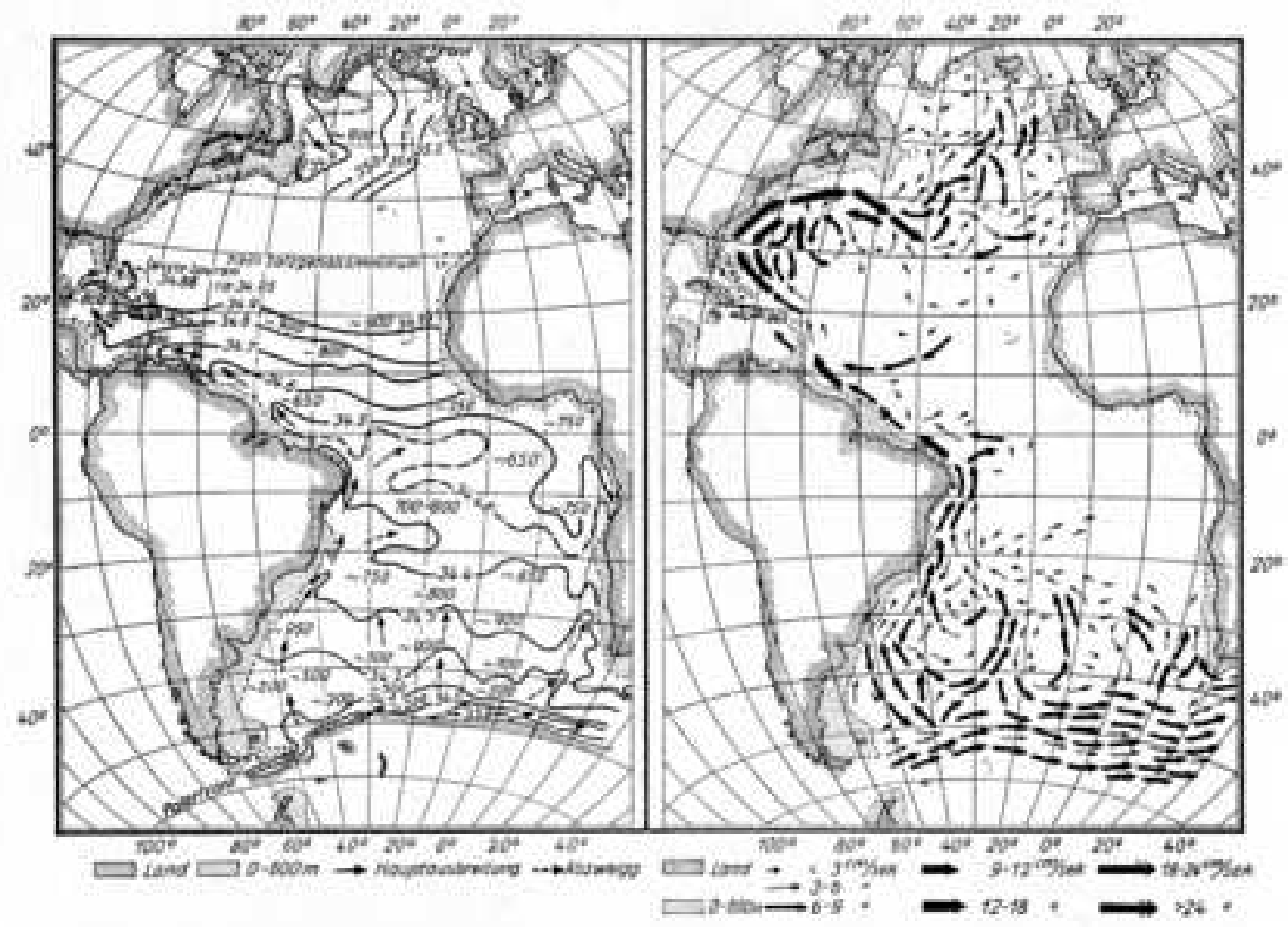


Figure 9

Click here to download high resolution image

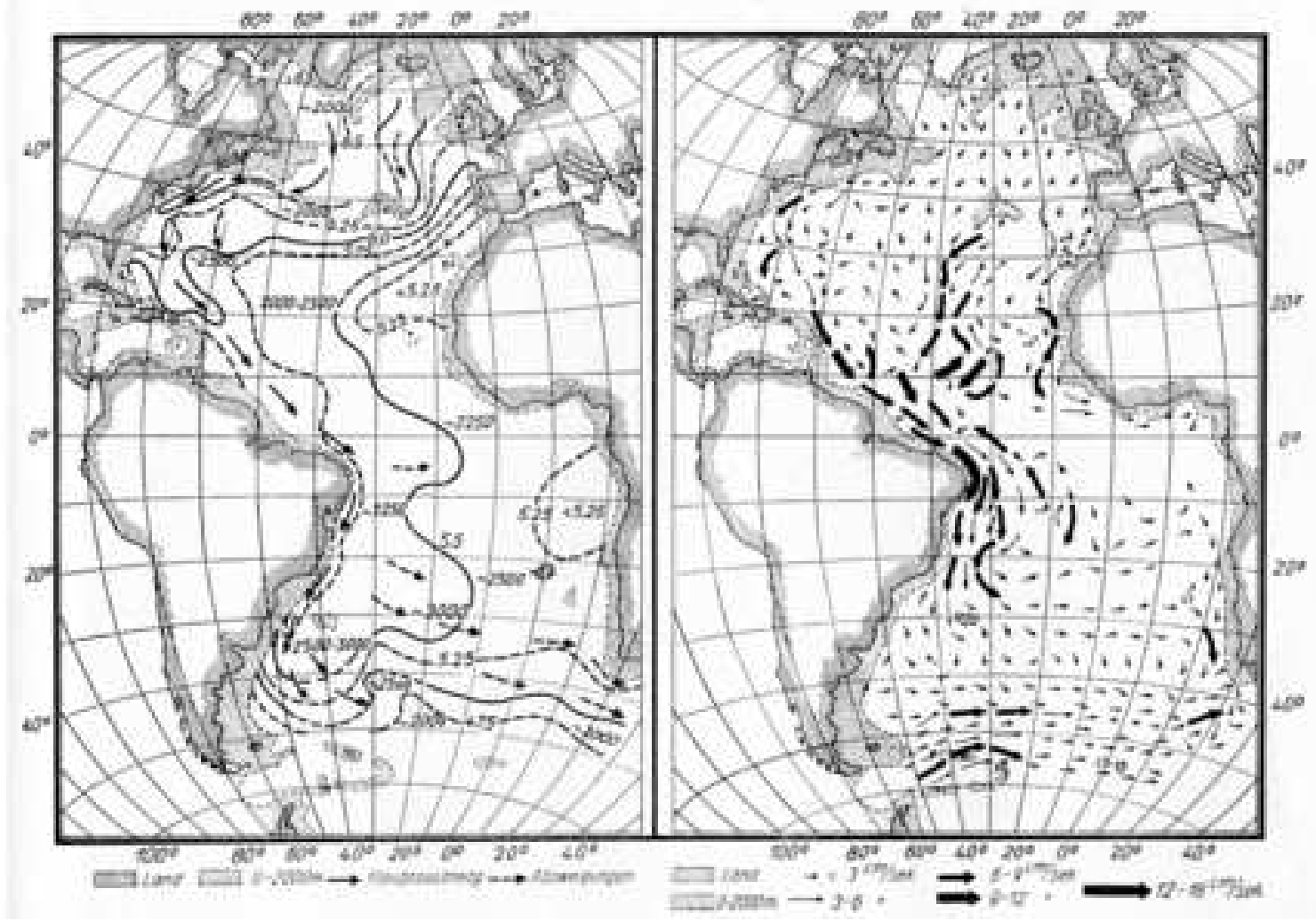


Figure 10
Click here to download high resolution image

(a)

(b)

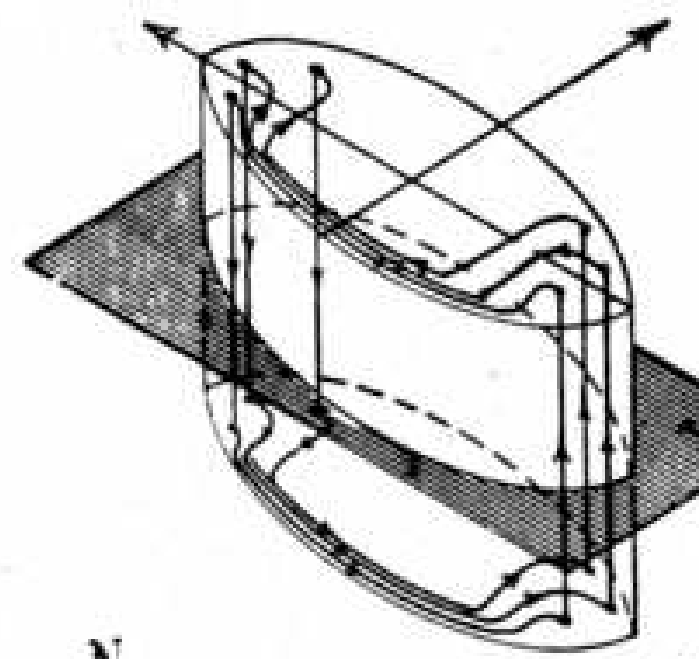

E

(c)
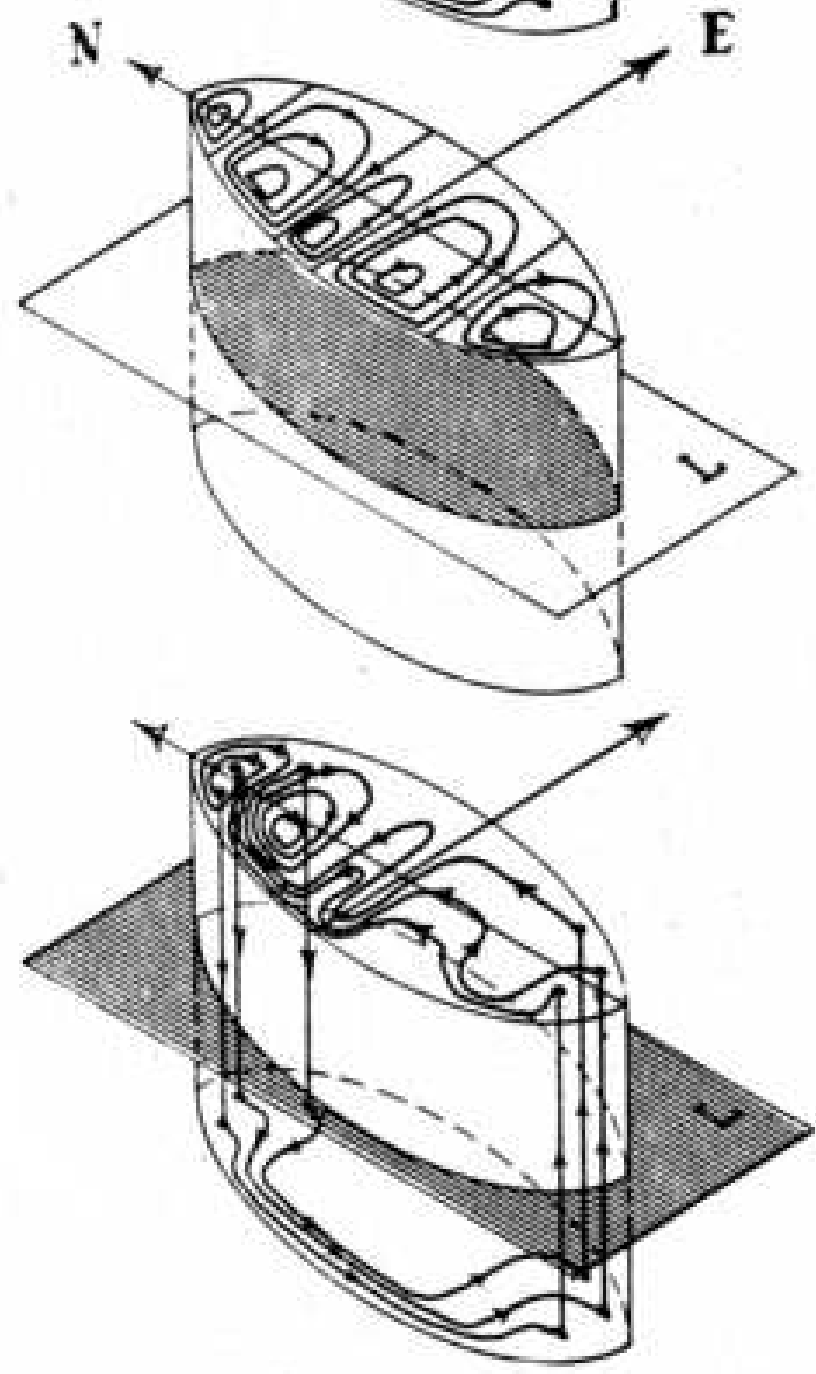


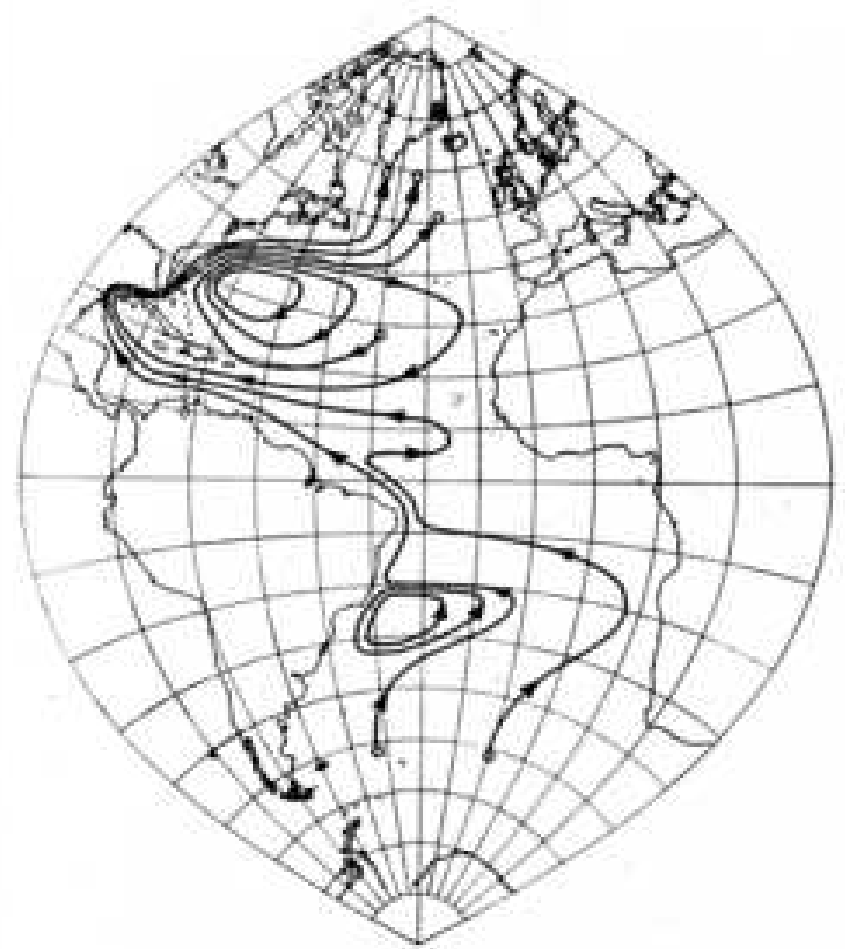

(a)

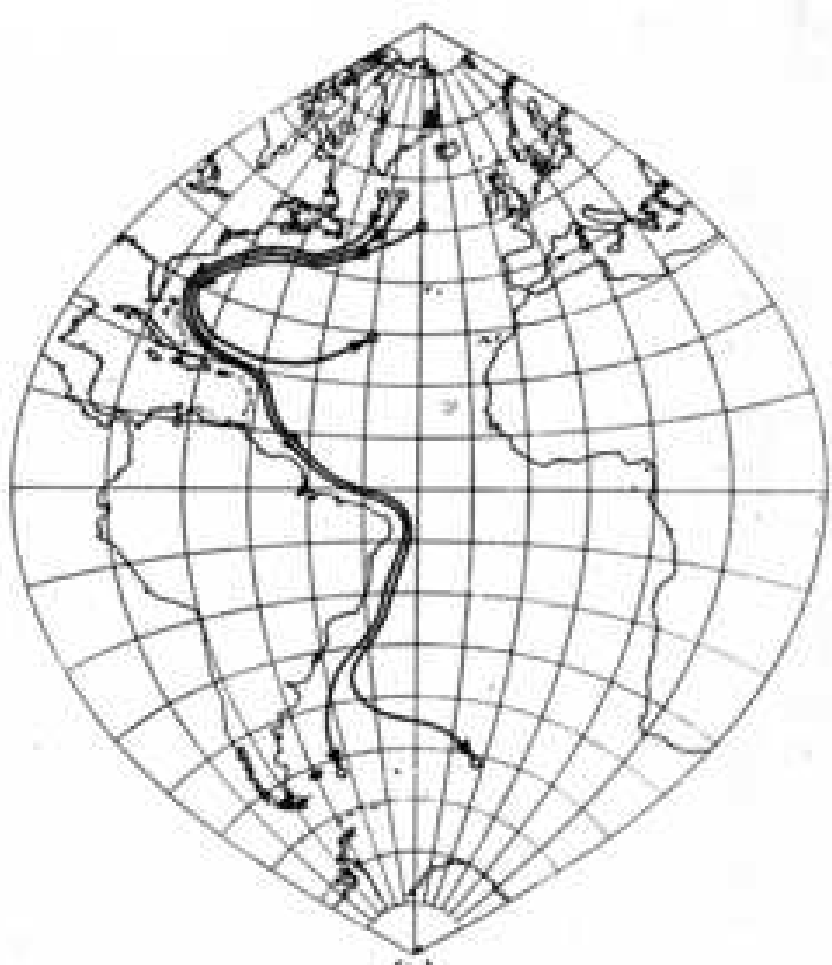

(b) 
Click here to download high resolution image

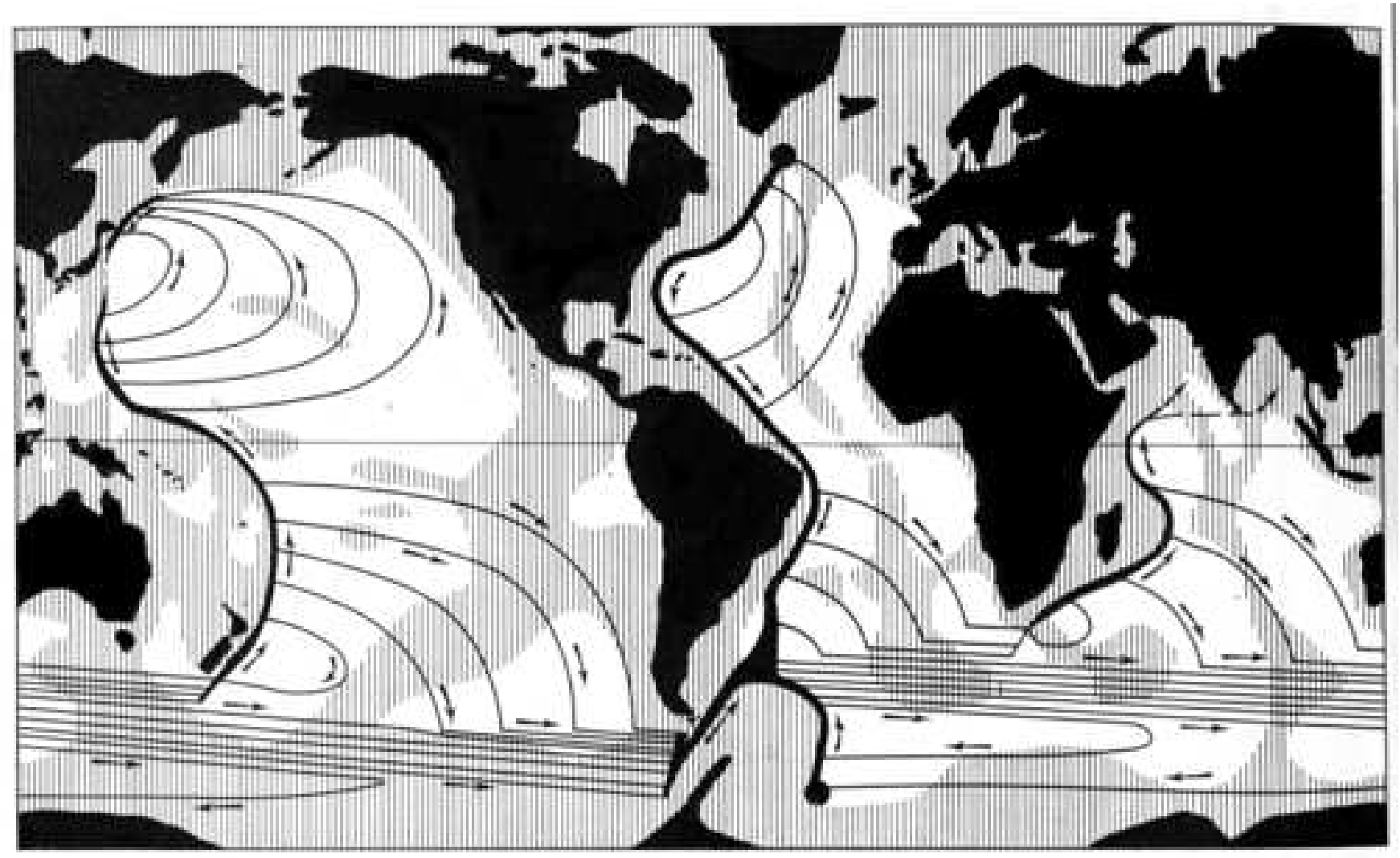


Figure 13
Click here to download high resolution image
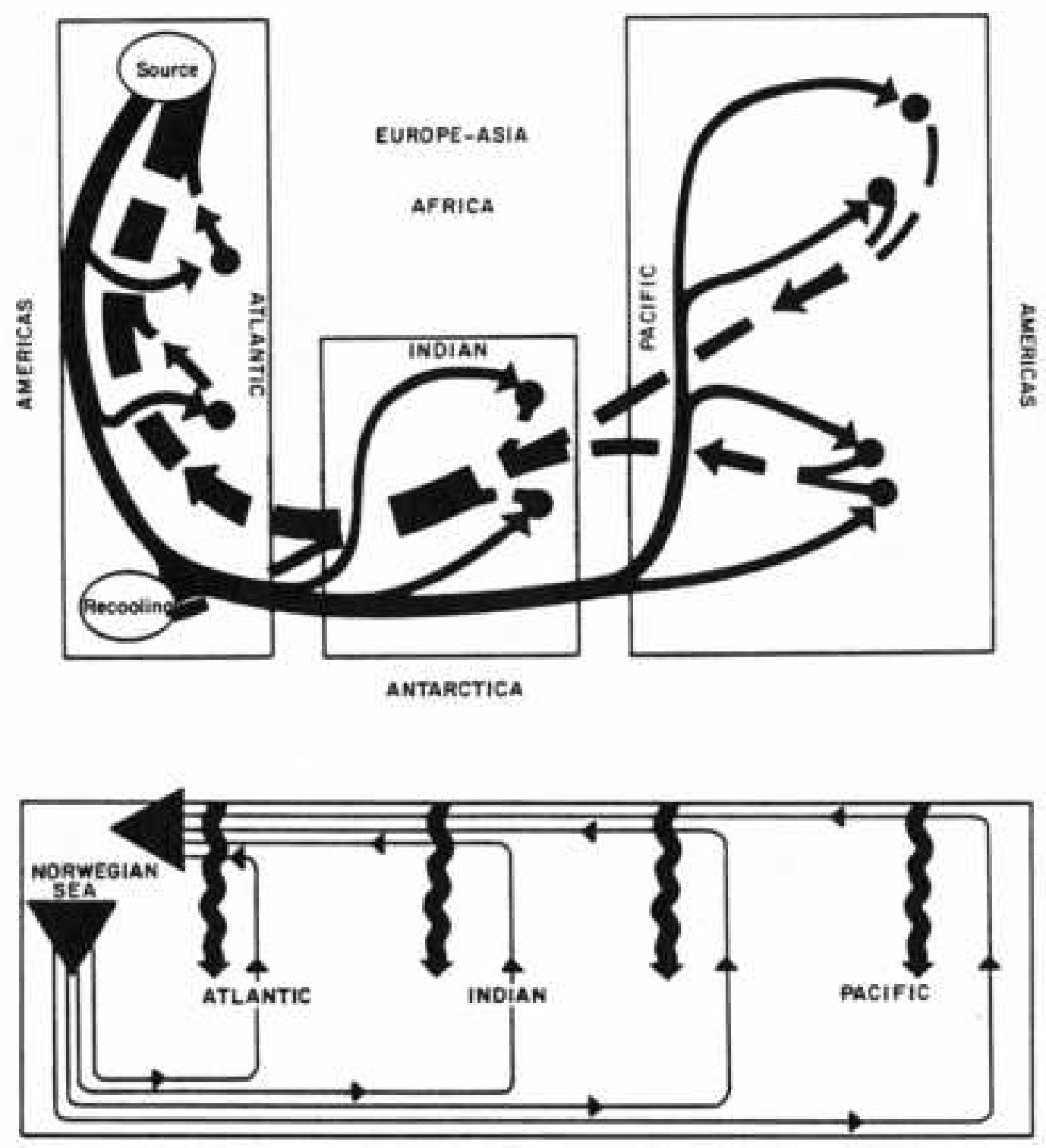
Figure 14
Click here to download high resolution image

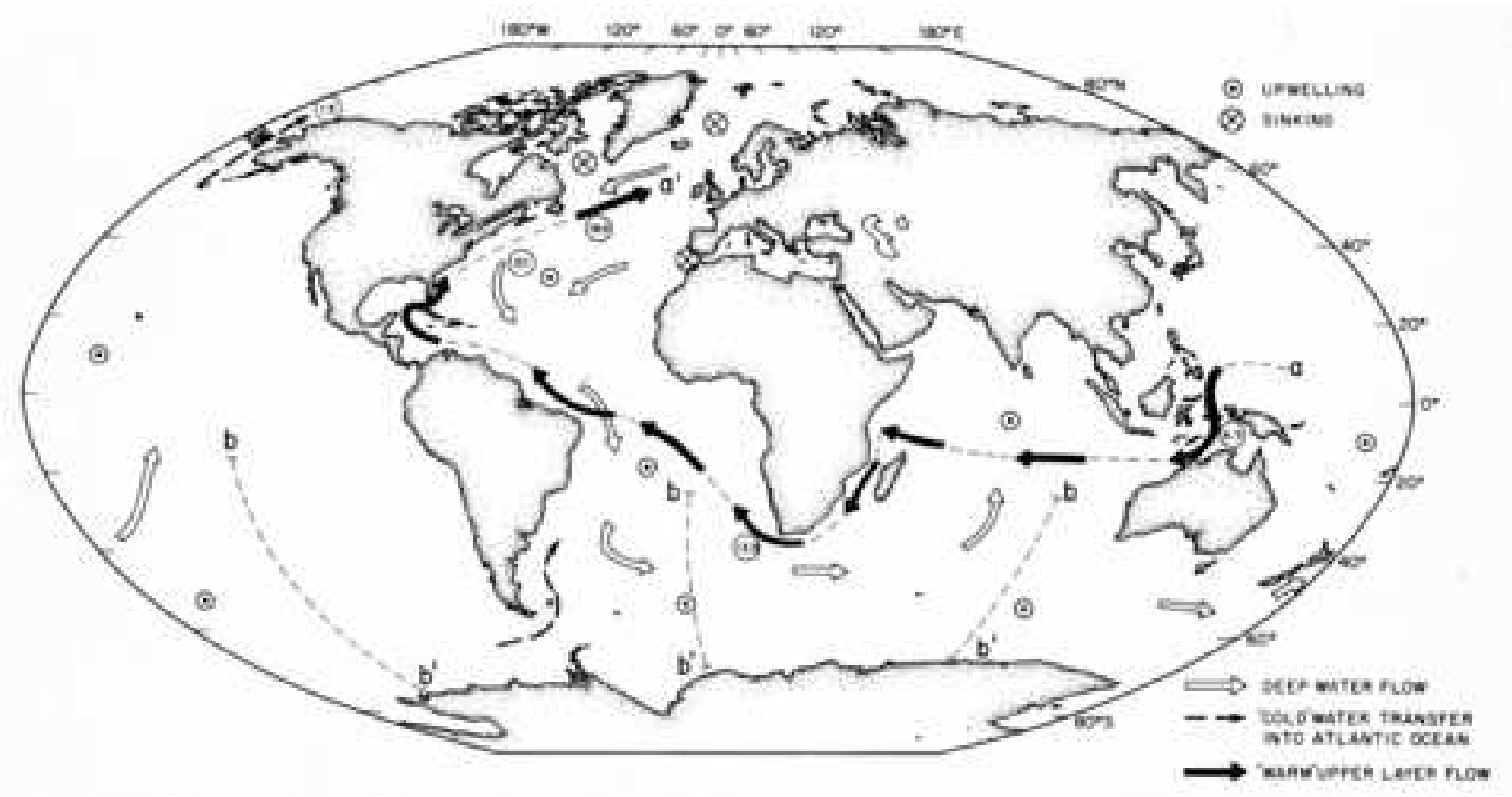


Figure 15
Click here to download high resolution image

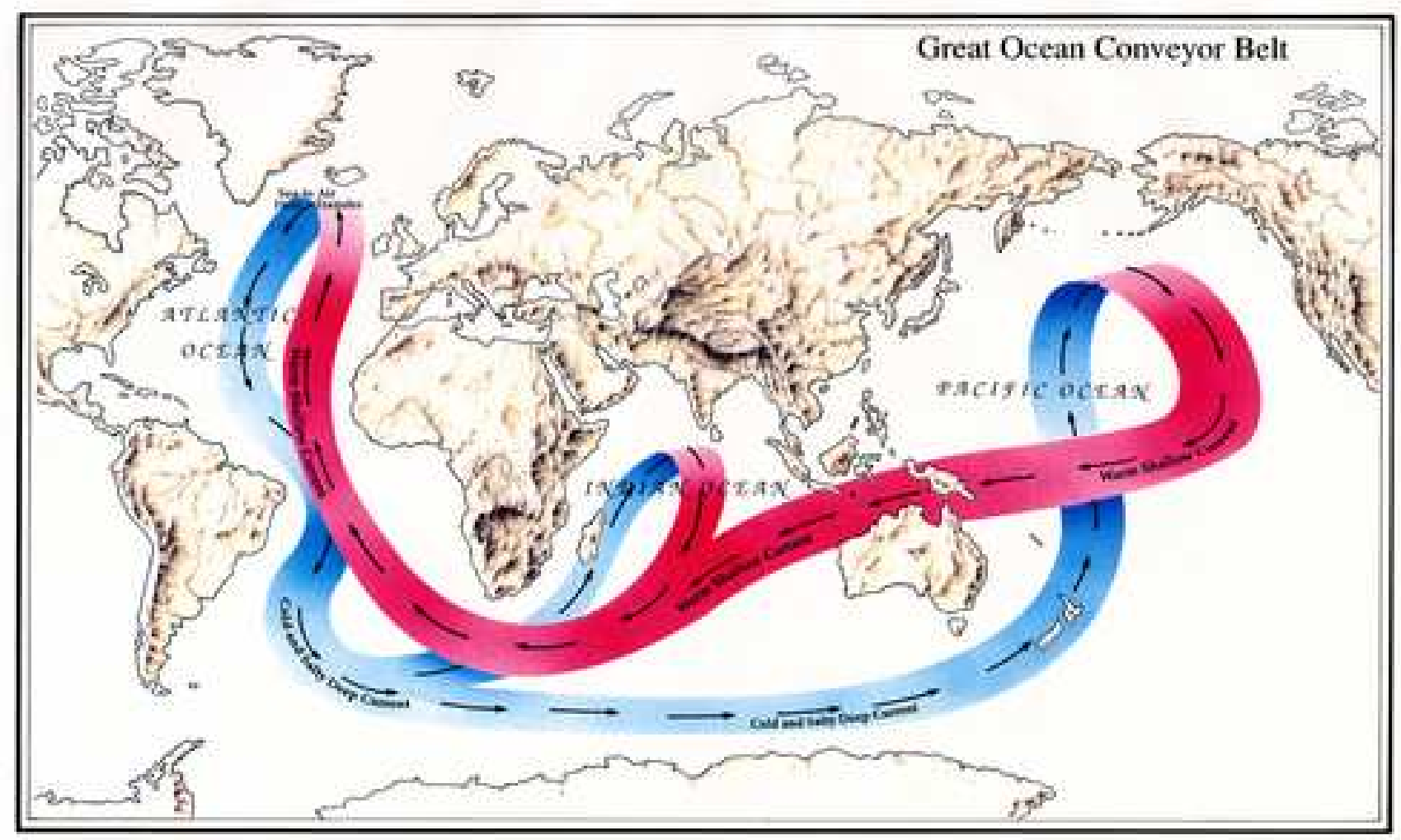




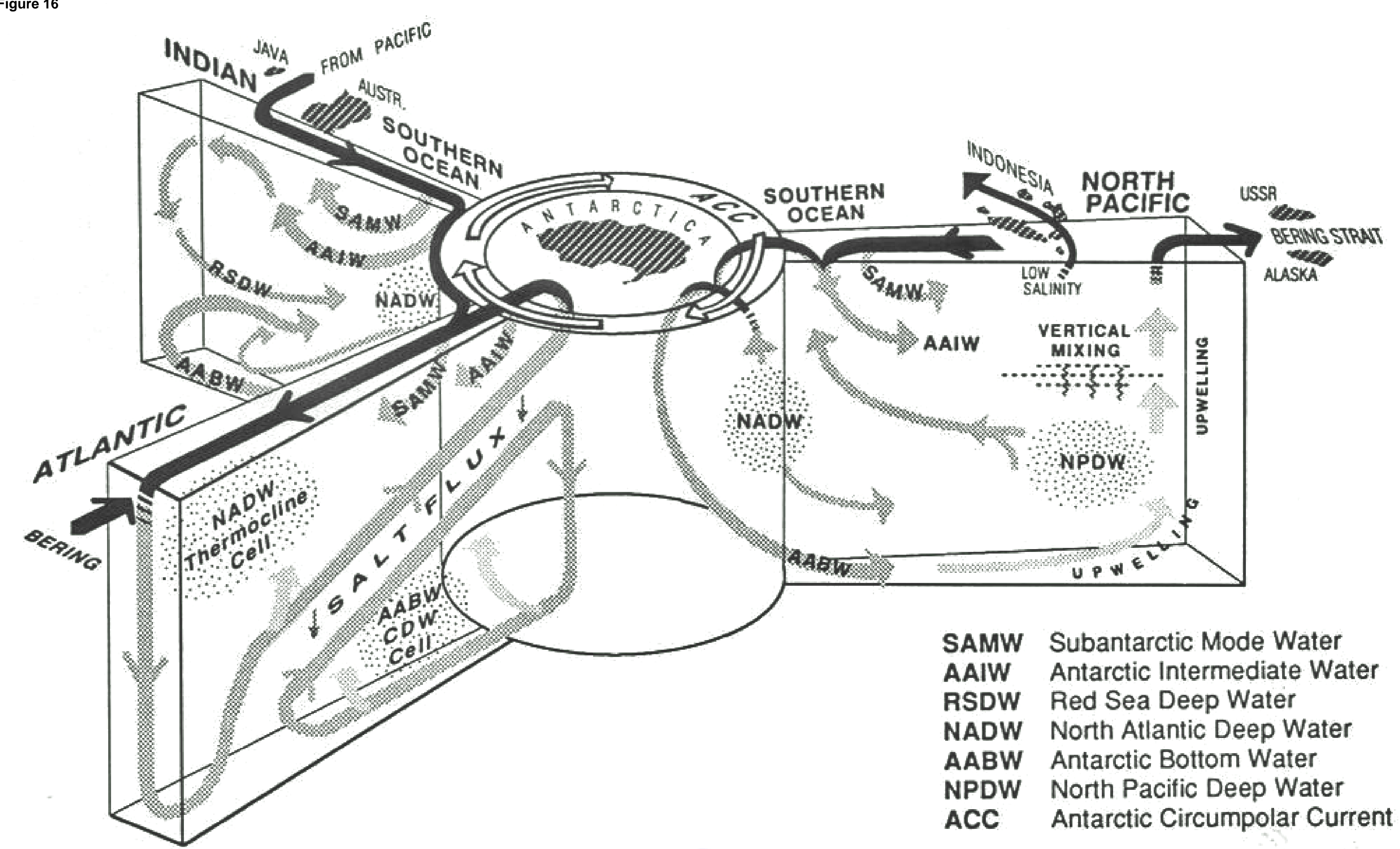


Figure 17
Click here to download high resolution image

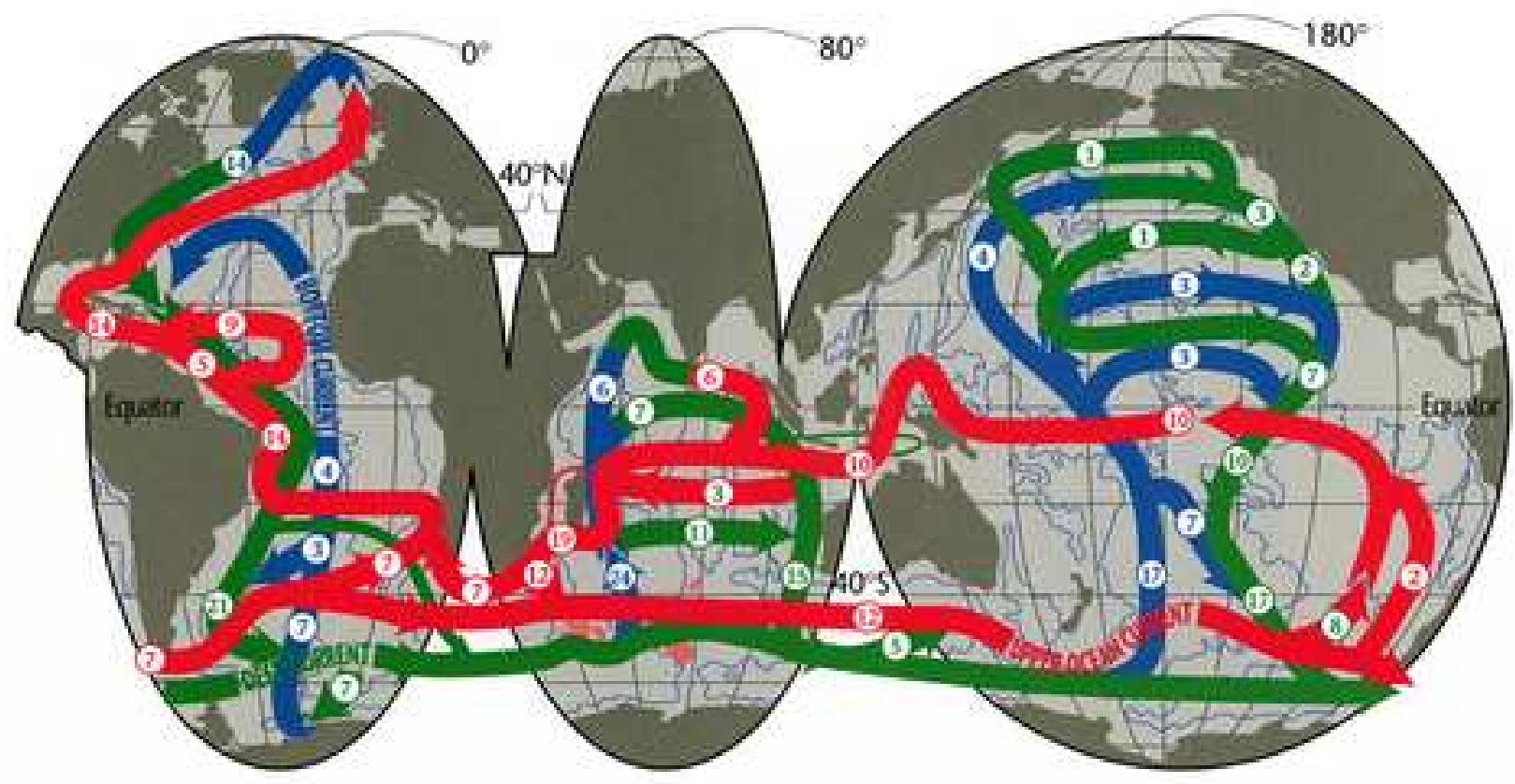

UPOCNW $\left[\sigma_{\theta} \leq 27.5(6)\right]$

Deep Water

Bottom Water

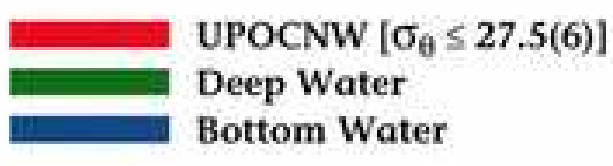

Q

\author{
Bottom Water
}


Click here to download high resolution image

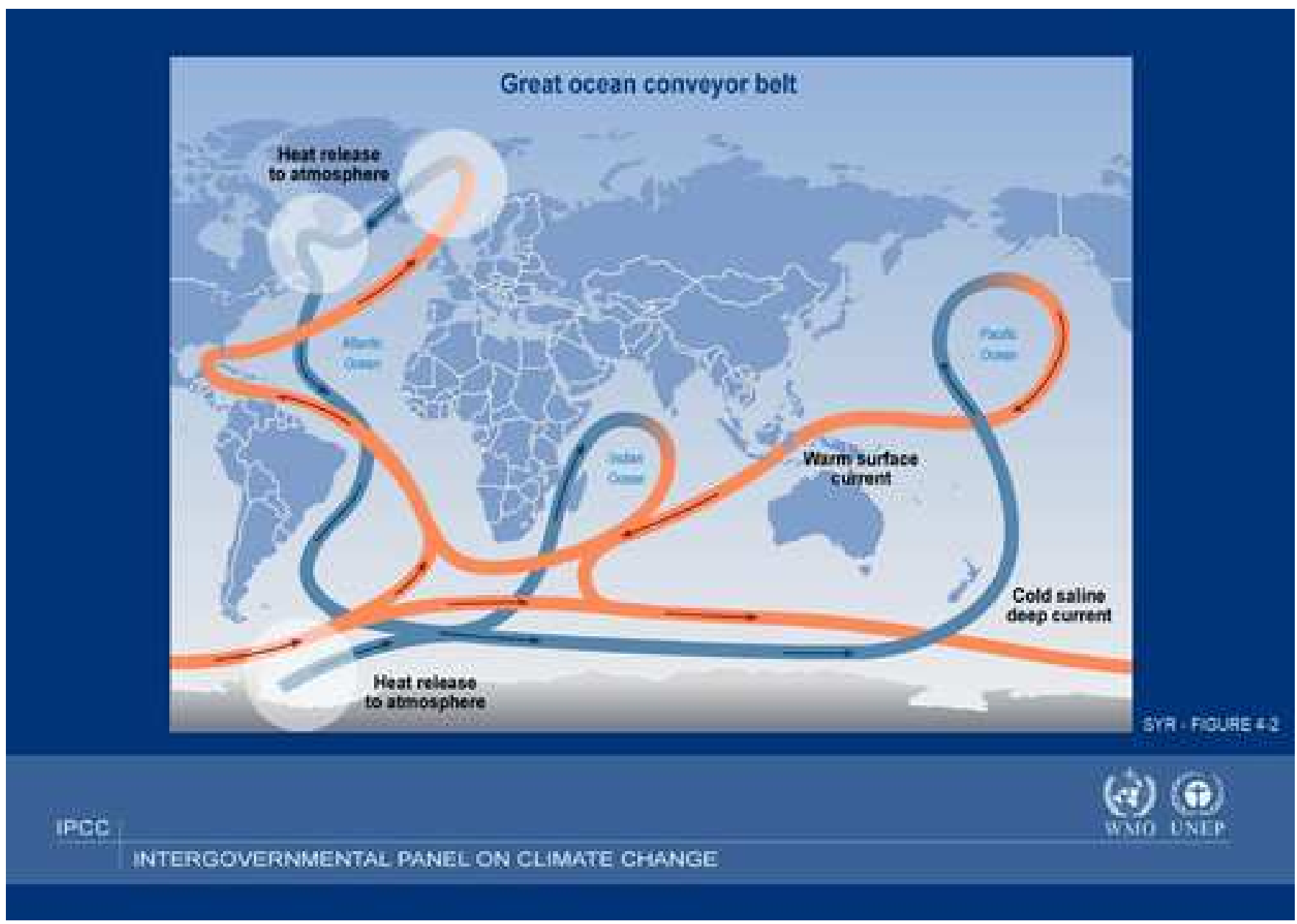

